\title{
Estradiol Selectively Enhances Auditory Function in Avian Forebrain Neurons
}

\author{
Melissa L. Caras, ${ }^{1,2}$ Matthew 0'Brien, ${ }^{3}$ Eliot A. Brenowitz, ${ }^{2,3,4}$ and Edwin W. Rubel2,4,5,6 \\ ${ }^{1}$ Neurobiology and Behavior Graduate Program, ${ }^{2}$ Virginia Merrill Bloedel Hearing Research Center, Departments of ${ }^{3}$ Biology, ${ }^{4}$ Psychology, \\ ${ }^{5}$ Otolaryngology-Head and Neck Surgery, and ${ }^{6}$ Physiology and Biophysics, University of Washington, Seattle, Washington 98195
}

\begin{abstract}
Sex steroids modulate vertebrate sensory processing, but the impact of circulating hormone levels on forebrain function remains unclear. We tested the hypothesis that circulating sex steroids modulate single-unit responses in the avian telencephalic auditory nucleus, field L. We mimicked breeding or nonbreeding conditions by manipulating plasma $17 \beta$-estradiol levels in wild-caught female Gambel's whitecrowned sparrows (Zonotrichia leucophrys gambelii). Extracellular responses of single neurons to tones and conspecific songs presented over a range of intensities revealed that estradiol selectively enhanced auditory function in cells that exhibited monotonic rate level functions to pure tones. In these cells, estradiol treatment increased spontaneous and maximum evoked firing rates, increased pure tone response strengths and sensitivity, and expanded the range of intensities over which conspecific song stimuli elicited significant responses. Estradiol did not significantly alter the sensitivity or dynamic ranges of cells that exhibited non-monotonic rate level functions. Notably, there was a robust correlation between plasma estradiol concentrations in individual birds and physiological response properties in monotonic, but not non-monotonic neurons. These findings demonstrate that functionally distinct classes of anatomically overlapping forebrain neurons are differentially regulated by sex steroid hormones in a dose-dependent manner.
\end{abstract}

\section{Introduction}

Sex steroid hormones modulate vocal signaling in adult vertebrates (Bass, 2008; Brenowitz, 2008), but how these modulations impact the auditory function of listeners remains unclear. Songbirds are well suited for addressing this issue. Song is a complex, learned vocalization that serves several functions, including species and individual identification, mate attraction, and territory defense (Catchpole and Slater, 1995). In seasonal breeders, such as Gambel's white-crowned sparrow, song behavior is sensitive to hormonal state; high levels of circulating sex steroid hormones, typical of the breeding season (Wingfield and Farner, 1978), increase singing rate, song duration, and song stereotypy (Smith et al., 1995; Meitzen et al., 2009a). Associated changes in the morphology and physiology of the neural circuit underlying song production are also observed (Nottebohm, 1981; Brenowitz et al., 1991; Smith et al., 1997; Tramontin et al., 2003; Soma et al., 2004; Park et al., 2005; Meitzen et al., 2007a,b, 2009b; Phillmore et al., 2011).

Recent work has explored the effect of sex steroid hormones on songbird auditory sensitivity at the level of the periphery and brain-

Received Aug. 17, 2012; revised 0ct. 9, 2012; accepted 0ct. 10, 2012.

Author contributions: M.L.C., E.A.B., and E.W.R. designed research; M.L.C. and M.O. performed research; M.L.C. analyzed data; M.L.C., E.A.B., and E.W.R. wrote the paper.

This work was supported by National Institutes of Health-National Institute on Deafness and Other Communication Disorders Grants F31DC010938, R01DC003829, and P30DC004661, the Seattle Chapter of Achievement Rewards for College Scientists Foundation, and the Washington Research Foundation. We thank Brandon Warren, David Schneider, and Sarah M. N. Woolley for technical assistance, Christine Portfors for her advice, and members of the Brenowitz and Rubel Laboratories for constructive discussion and support.

The authors declare no competing financial interests.

Correspondence should be addressed to Dr. Edwin W. Rubel, Virginia Merrill Bloedel Hearing Research Center, University of Washington, Mail Stop 357923, Seattle, WA 98195. E-mail: rubel@uw.edu.

DOI:10.1523/JNEUROSCI.3938-12.2012

Copyright $\odot 2012$ the authors $\quad 0270-6474 / 12 / 3217597-15 \$ 15.00 / 0$ stem (Henry and Lucas, 2009; Caras et al., 2010). Additional studies have examined the impact of sex steroid hormones on the processing of song stimuli in regions specialized for song perception or production such as the sensorimotor nucleus HVC (proper name), the caudomedial nidopallium (NCM) or the caudomedial mesopallium (CMM) (Maney et al., 2006; Tremere et al., 2009; Remage-Healey et al., 2010, 2012; Sanford et al., 2010; Phillmore et al., 2011; Tremere and Pinaud, 2011; Remage-Healey and Joshi, 2012).

Many issues remain unexplored. First, neurons in NCM, the main focus for the majority of studies on this topic, express hormone receptors (Bernard et al., 1999; Gahr, 2001; Jeong et al., 2011). Receptor expression is not a prerequisite for hormonal sensitivity, however, as steroid action can be mediated via other neuromodulatory systems (Maney and Pinaud, 2011). It is therefore of interest to determine whether auditory regions upstream of NCM, some of which lack sex steroid receptors, are also affected by hormonal state. Similarly, it is unclear whether circulating sex steroids modulate fundamental aspects of auditory processing in the forebrain, and if so, whether the magnitude of these modulations depends on the plasma level of hormone. To address these questions, we brought adult female sparrows into breeding [high $17 \beta$-estradiol $\left(\mathrm{E}_{2}\right)$ ] or nonbreeding condition $\left(\right.$ low $\mathrm{E}_{2}$ ) in the laboratory and made in vivo extracellular recordings from single units in the forebrain field $\mathrm{L}$ complex. Field $\mathrm{L}$ is the primary thalamic recipient of auditory information and is analogous to mammalian primary auditory cortex (Fortune and Margoliash, 1992; Vates et al., 1996; Reiner et al., 2004) (see Fig. $1 B)$. Unlike cells in downstream nuclei, field $\mathrm{L}$ neurons do not express steroid receptors (Jeong et al., 2011; Maney and Pinaud, 2011). We found that modulations of systemic $E_{2}$ affect many fundamental response properties in monotonic field $\mathrm{L}$ neurons. 


\section{Materials and Methods Subjects}

Adult female Gambel's white-crowned sparrows $(n=21)$ were captured in eastern Washington state during autumn and spring migrations between 2007 and 2011. Birds were housed in outdoor aviaries at the University of Washington for up to 30 weeks before being moved to indoor aviaries. Once inside, all birds were housed in groups on a short-day

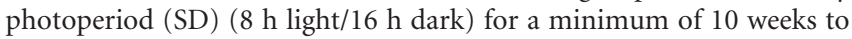
ensure sensitivity to the stimulating effects of hormones and photoperiod (Wingfield et al., 1979). Food and water were available ad libitum. All procedures were approved by the Institutional Animal Care and Use Committee at the University of Washington, Seattle.

\section{Hormone and photoperiod manipulations}

Birds were brought into either nonbreeding-like condition or breedinglike condition in the laboratory. To induce a nonbreeding condition, we housed birds $(n=12)$ on a SD photoperiod as above. Birds housed on a SD photoperiod maintain regressed gonads, have basal plasma sex hormone levels, and display neural morphology and physiology typical of the nonbreeding season (Middleton, 1965; Smith et al., 1995; Tramontin et al., 2000; Park et al., 2005; Meitzen et al., 2007b). To induce a breeding condition, we housed birds $(n=9)$ on a long day (LD) $(20 \mathrm{~h} \mathrm{light} / 4 \mathrm{~h}$ dark) photoperiod typical of their Alaskan breeding grounds and implanted them with subcutaneous hormone pellets made from SILASTIC tubing (inner diameter, $1.0 \mathrm{~mm}$; outer diameter, $2.0 \mathrm{~mm}$, length, $12 \mathrm{~mm}$; VWR). Pellets were filled with crystalline $\mathrm{E}_{2}$, rinsed in ethanol, and soaked overnight in $0.1 \mathrm{~m}$ PBS before implantation (Tramontin et al., 2003). Supplemental hormone is necessary to raise plasma hormone levels of laboratory-housed birds to physiological levels observed in breeding birds in the wild (Smith et al., 1995). Birds were housed under these conditions for 3 weeks; this time period is sufficient to induce neural morphology and physiology typical of the breeding season (Tramontin et al., 2000; Park et al., 2005; Meitzen et al., 2007b).

\section{Electrophysiology \\ Surgical procedures}

All experiments took place in a double-walled acoustically isolated chamber (Acoustic Systems). At the beginning of each experiment, birds were anesthetized with $25 \%$ urethane $(6 \mu \mathrm{l} / \mathrm{g}$ body weight; Thermo Fisher Scientific), divided evenly into three intramuscular injections separated by $30 \mathrm{~min}$. Supplementary doses $(0.67 \mu \mathrm{l} / \mathrm{g})$ were delivered throughout the experiment to maintain anesthetic state as assessed by toe pinch. After birds were fully anesthetized, we injected $0.1 \mathrm{ml}$ of $1 \%$ lidocaine (APP Pharmaceuticals) subcutaneously at the dorsal midline of the skull, made an incision, and removed the skin and fascia. A metal post was fixed to the skull with dental cement (Lang Dental), and birds were secured to a head holder/stereotaxic device. Body temperature was maintained at $40-42^{\circ} \mathrm{C}$ by a heating pad using a cloacal thermal probe and digital controller (TC-1000 Temperature Controller; CWE). A small craniotomy was made dorsal to field $\mathrm{L}$ in the right hemisphere using stereotaxic coordinates relative to the bifurcation of the midsagittal sinus $(1.4 \mathrm{~mm}$ lateral, $1.8-2.3 \mathrm{~mm}$ anterior). The dura was removed and a glass micropipette electrode (5-19 $\mathrm{M} \Omega$ impedance) filled with 10\% Fluoro-Ruby [10,000 molecular weight (MW) tetramethylrhodamine dextran; Invitrogen] or $10 \%$ biontinylated detran amine (BDA) (10,000 MW, Invitrogen) in $0.9 \% \mathrm{NaCl}$ was positioned over the opening. The electrode was advanced by an electric microdrive (Newport), which was controlled by the experimenter from outside the sound attenuation booth. For some recording sessions, the craniotomy opening was covered in petroleum jelly to prevent tissue dehydration. We made one to three electrode penetrations in each bird. Although we recorded activity at a wide range of depths $(\sim 800-3300 \mu \mathrm{m})$, we restricted our analysis to units that were confirmed histologically to be within field L (see below, Electrode track reconstruction).

Auditory processing is lateralized in songbirds, although the exact nature of hemisphere specificity depends on sex, species, brain area, anesthetic state, stimulus selection, and method of analysis (Cynx et al., 1992; George et al., 2004, 2005; Avey et al., 2005; Hauber et al., 2007;
Poirier et al., 2009; Phan and Vicario, 2010). To avoid introducing a lateralization confound into our experimental design, we chose to focus only on the right hemisphere.

\section{Stimulus delivery and calibration}

The stimulus delivery system we employed has been used previously (Caras et al., 2010). Briefly, a small speaker (Etymotics ER-2B) and microphone (Etymotics ER-10B) were enclosed within a custom-made sound delivery tube and positioned flush against the skull surrounding the left external auditory meatus. Petroleum jelly was applied to the outside of the tube and skull, creating a closed sound delivery system. Sound delivery was controlled by custom scripts (Python) running on a computer located outside the sound attenuation chamber. Stimuli were routed through an RX6 multifunction processor (Tucker-Davis Technologies) that performed both digital/analog conversion and attenuation of the signal before delivery to the speaker.

Before each experiment, we used random-phase band-limited $(6 \mathrm{~Hz}$ to $20 \mathrm{kHz}$ ) white noise to calibrate pure-tone sound pressure levels (decibels SPL re: $20 \mu \mathrm{Pa}$ ). For our initial experiments, we used the white-noise generated calibration table to determine root-mean squared sound pressure levels (RMS decibels SPL) for song stimuli. In later experiments, we presented individual songs to the microphone and determined RMS decibel SPL values separately for each song. The levels for earlier recordings were corrected for each song type presented. RMS amplitudes for song stimuli were reliable within $\leq 4.9 \mathrm{~dB}$ SPL.

\section{Auditory stimuli}

We presented two different types of stimuli in this study. Pure-tone stimuli were $100 \mathrm{~ms}$ in duration with $5 \mathrm{~ms}$ linear ramp rise-fall times. Tones were generated on-line using the same custom software that controlled sound delivery. Song stimuli consisted of a set of songs recorded from seven individual male sparrows held under breeding condition in the laboratory. We used male songs because females of this species do not sing. We recorded songs using Syrinx software (John Burt; www.syrinxpc. com, University of Washington, Seattle, WA) and previously published protocols (Meitzen et al., 2007b, 2009a). Low-frequency background noise was digitally filtered off-line. We recorded one song from each bird, for a total of seven songs.

Gambel's white-crowned sparrow songs typically consist of five syllables: a whistle, a warble, and three buzzes (see Fig. $1 A$ ). The songs presented in this study were $2.15 \pm 0.19 \mathrm{~s}$ in duration (mean $\pm \mathrm{SD}$ ) and spanned an average frequency range of $2.44-5.98 \mathrm{kHz}$. These values are similar to those previously published for a larger song set (Meitzen et al., 2009a).

The majority of song stimuli (see Fig. $1 A, 1$ through 4) were recorded from captive males before 2007, and thus were unfamiliar to all of our experimental birds. Three songs (see Fig. $1 A, 5$ through 7) were recorded from males that had overlapping periods of captivity with some of the experimental birds, and therefore may have been familiar. Although song familiarity can affect neurophysiological responses in more specialized auditory regions, such as NCM, field L does not display this characteristic (Theunissen et al., 2004). We therefore did not include song familiarity as a factor in our data analysis.

\section{Data acquisition}

We recorded the extracellular activity of well isolated single units. Spikes were amplified 10,000 $\times$ (ISO-80; World Precision Instruments; and MA3; Tucker-Davis Technologies), bandpass filtered $0.1-10 \mathrm{kHz}$ with a $24 \mathrm{~dB} /$ octave roll-off (Krohn-Hite model 3550), digitized at 24.4 samples/s (RX6 multifunction processor; Tucker-Davis Technologies), and monitored on-line via a digital oscilloscope and audio speaker. Custom data acquisition software displayed spike trains, isolated waveforms, and raster plots in real time. We analyzed raw waveforms off-line using custom MATLAB scripts (David Schneider and Sarah Woolley, Columbia University, New York, NY) to ensure that only well isolated single units were included in the dataset. Neurons were assessed to be well isolated by the following criteria: (1) a stable waveform shape, (2) a high (>4) signalto-noise ratio, and ( 3 ) the absence of any interspike intervals $<1 \mathrm{~ms}$. The vast majority of recordings (71 of 77) met all three criteria. The remaining six recordings demonstrated the presence of two clearly separable 
waveforms with high signal-to-noise ratios. These waveforms were manually sorted off-line; sorting efficacy was additionally verified by principal-components analysis.

Band-limited white noise $(0.25-8 \mathrm{kHz})$ at $80 \mathrm{~dB}$ SPL was used as a search stimulus. Once a unit was well isolated, we presented song and tone stimuli, with the order of presentation randomized across cells. For song trials, we chose one song exemplar at random and presented it from 90 to $10 \mathrm{~dB}$ SPL in $10 \mathrm{~dB}$ descending steps at a rate of $0.14 / \mathrm{s}$. We recorded 5-10 trials at each intensity. For tone presentations, we initially estimated the characteristic frequency $(\mathrm{CF})$ and best threshold of the unit on-line. We then presented a range of frequencies around the $\mathrm{CF}$, in increments approximately equal to $10 \%$ of the CF. Each frequency was presented from 90 to $10 \mathrm{~dB}$ SPL in $10 \mathrm{~dB}$ descending steps at a rate of $1.25 / \mathrm{s}$ to construct the full response area of the unit. We recorded 5-10 trials for each frequency-intensity pair, with the order of frequency presentation randomized across trials.

It should be noted that the stimulus intensities used here $(10-90 \mathrm{~dB}$ SPL) are similar to the sound amplitudes that would be experienced by free-living birds in the wild. Avian species are capable of singing at high intensities, with maximum values ranging from 74 to $105 \mathrm{~dB}$ SPL at $1 \mathrm{~m}$ (Brackenbury, 1979; Brenowitz, 1982), although some species can generate song amplitudes as high as $111.5 \mathrm{~dB}$ SPL [e.g., the Screaming Piha (Lipaugus vociferans) (Nemeth, 2004)]. Therefore, we consider the stimulus levels used here to be within a normal, ethologically relevant range.

\section{Data analysis}

Tone responses. A unit was considered tone responsive if its average stimulus-evoked firing rate was significantly different (Student's paired $t$ test, $p<0.05$ ) than its average spontaneous firing rate (calculated from the $100 \mathrm{~ms}$ immediately preceding tone onset). The vast majority (54 of 56) of tone responses were excitatory. The remaining two cells (one from a nonbreeding female, one from a breeding female) gave what appeared to be postinhibitory rebound responses, as evidenced by strong excitation immediately following tone offset. If these cells were truly exhibiting postinhibitory rebound, their firing rates should be suppressed during tone presentation. The spontaneous firing rates of the cells were already quite low (1.48 and 1.67 spikes (sp)/s, respectively), however, making it difficult to detect a suppressive response. Because these potentially suppressive responses were so rare, we removed them from the tone analyses. Both of these cells did show suppressive responses to songs and were included in the song analyses (see below, Song responses).

To determine the pure-tone sensitivity of a unit, we measured the threshold for each stimulus frequency. Threshold was defined as the lowest intensity (decibels SPL) to elicit a significant response. An additional criterion was that successively higher level stimuli must also elicit reliable responses. The $\mathrm{CF}$ was identified as the stimulus frequency with the lowest threshold. If multiple frequencies had the same (lowest) threshold, CF was defined as the stimulus with the greatest response strength (RS) at threshold. Here, we define RS as the difference between the average stimulus-evoked firing rate and the average spontaneous firing rate during the $100 \mathrm{~ms}$ immediately preceding tone onset, a window equal to the duration of the tone.

We measured the frequency bandwidth $10 \mathrm{~dB}$ above the best threshold of the neuron as an indicator of frequency tuning. In addition we made the following measurements of the responses to the CF: First, we identified the maximum average evoked firing rate, and the stimulus intensity that elicited the maximum response (max decibels). Second, we set a noise floor 2 SDs above the baseline rate of the neuron. We then defined the firing rate range (spikes per second) of the neuron as the difference between the noise floor and the maximum evoked firing rate. Third, we calculated the dynamic range of the neuron, or the range of stimulus intensities within which a neuron is sensitive to differences in intensity. The dynamic range (decibels SPL) was calculated as the difference between the max decibels and the threshold.

During the early phases of our studies, it became clear that neuronal responses in field $\mathrm{L}$ could be either monotonically related to tone intensity at CF, or non-monotonic. Monotonic and non-monotonic neurons are thought to play different roles in auditory coding (Polley et al., 2006; Sadagopan and Wang, 2008; Watkins and Barbour, 2011), raising the possibility that breeding condition might modulate each neuronal population in a distinctive manner. We therefore chose to analyze monotonic and non-monotonic responses separately, as discussed below.

To objectively determine whether a cell should be considered monotonic or non-monotonic, we set a boundary halfway between the noise floor and the maximum average evoked firing rate. A neuron was considered non-monotonic if its average evoked firing rate dropped below this boundary at stimulus intensities above the decibel level that evoked the maximum firing rate. If the cell maintained a high evoked firing rate, staying above this boundary, it was considered monotonic (see Fig. 2).

To determine whether these categorizations truly reflected two separate populations of neurons, we calculated a monotonicity index (MI) for each cell. The MI ranges from 0 to 1 , with increasing values indicative of increasing degrees of monotonicity. Similar measures of monotonicity have been used previously by other researchers (Sutter and Schreiner, 1995; Recanzone et al., 2000; de la Rocha et al., 2008; Watkins and Barbour, 2011). The MI was calculated for each cell as follows: MI = Rate evoked at highest pure-tone amplitude presented/ maximum evoked rate of the neuron. In the majority of our cases ( 27 of 28 monotonic and 23 of 25 non-monotonic neurons), the highest pure-tone amplitude tested was $90 \mathrm{~dB}$ SPL. In the remaining three cases, the highest amplitude tested was $80 \mathrm{~dB}$ SPL.

One non-monotonic neuron recorded in a breeding female had particularly strong tone and song responses. To determine whether this cell was an outlier, we averaged tone and song-evoked $|\mathrm{RS}|$ values separately across stimulus level for each non-monotonic cell recorded under breeding condition. We used these average values to perform Dixon's $Q$ test for outliers (Dixon, 1950). We found that the cell in question was an outlier at the 99th confidence interval (Rorabacher, 1991) for both tone and song-evoked responses. We therefore removed this cell from all analyses.

Song responses. To determine whether a unit was responsive to song, we first established a noise floor 2 SDs above and below the spontaneous rate of the neuron. For a unit to be considered song responsive, its evoked firing rate had to fulfill the following criteria at a minimum of two consecutive song intensities: (1) surpass the noise floor and (2) be statistically different (Student's paired $t$ test, $p<0.05$ ) than the average spontaneous firing rate during the $2000 \mathrm{~ms}$ immediately preceding song onset, a window approximately equal to the duration of each song stimulus. We found that these criteria reliably included units that were considered responsive by an experienced observer, while minimizing false positives. Two neurons clearly responded to song, but only at the highest stimulus intensity tested, and therefore could not meet the response criteria. An observer experienced in single-unit physiology blinded to the experimental conditions examined raster and poststimulus time histogram (PSTH) plots. A decision to include these cells in the analysis was made after this observer agreed that the neurons showed increased activity during song presentation.

A unit's song threshold (decibels SPL) was defined as the lowest of at least two consecutive intensities to elicit a significant response. We then identified the maximum average evoked firing rate (for excitatory song responses), the minimum average evoked firing rate (for suppressive song responses), and the stimulus intensity that elicited the maximum or minimum firing rate (max or min decibels, respectively). We calculated the song dynamic range (decibels SPL) as the difference between max or min $\mathrm{dB}$ and the threshold. Finally, similar to tones, we used RS (spikes per second) as a measure of response magnitude. Songs elicited both excitatory and suppressive responses (see Fig. 6), however, which resulted in positive and negative RS values, respectively. To analyze all song responses as a whole, we used the absolute value of RS.

\section{Electrode track reconstruction}

Two injections of either 10\% Fluoro-Ruby (20 of 21 birds) or $10 \%$ BDA ( 1 of 21 birds) were made at the end of each electrode penetration to enable off-line reconstruction of recording sites. Fluoro-Ruby was injected iontophoretically through the recording pipette by using a current source (BAB-501; Kation Scientific) set to $+10 \mu \mathrm{A}$ for 1 min, followed by $+4 \mu \mathrm{A}$ (alternating $7 \mathrm{~s}$ on/off) for $8 \mathrm{~min}$. BDA was injected with 5-10 rapid $40 \mathrm{~ms}$ pulses of nitrogen gas at 20 psi using a picospritzer (Parker). 

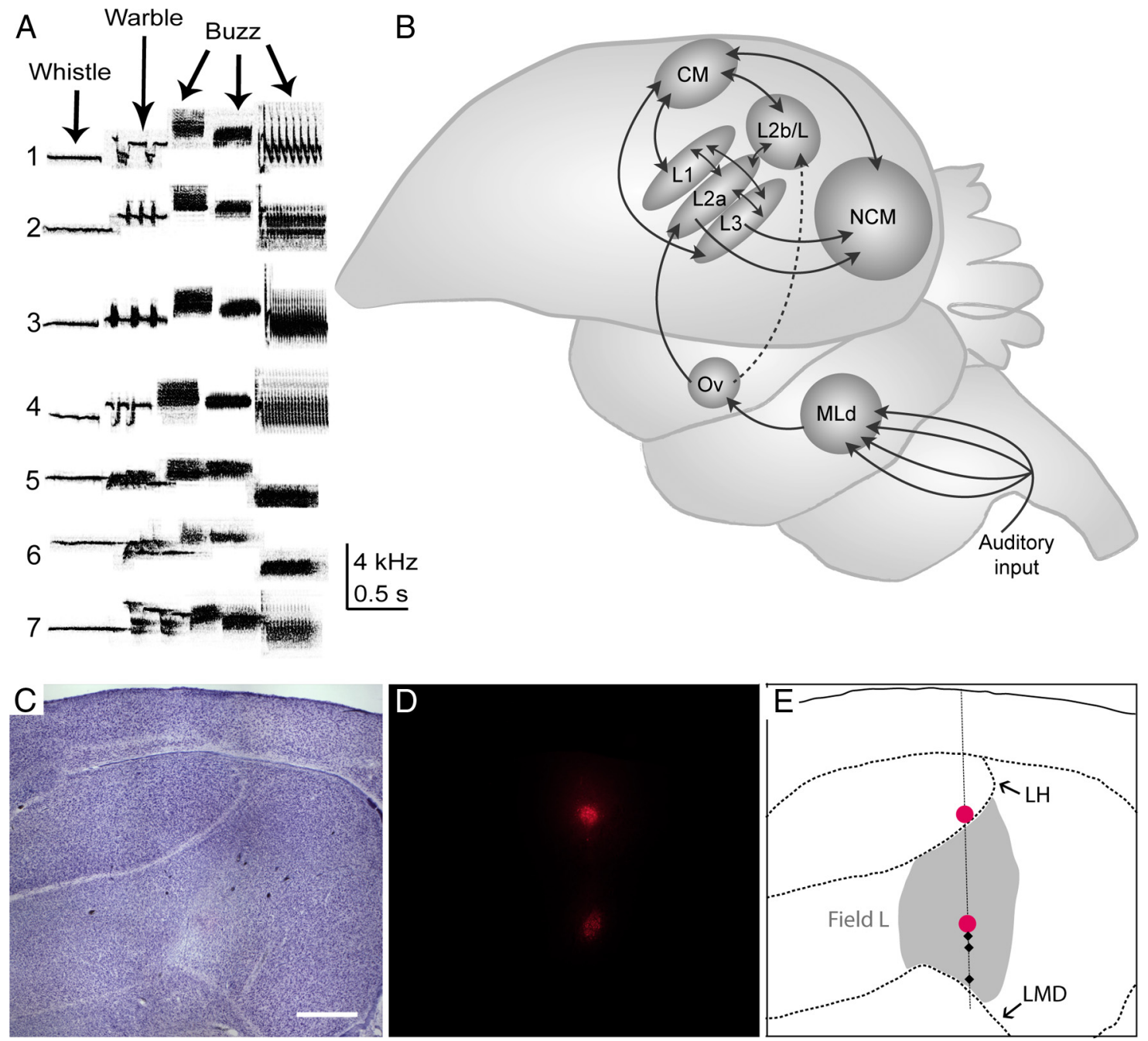

Figure 1. Experimental song stimuli, avian auditory schematic, and histological reconstruction. $A$, Individual Gambel's white-crowned sparrow songs were recorded from seven wild-caught males and used as sound stimuli in this study. Typical white-crowned songs consist of five syllables: a whistle, a warble, and three buzzes. In each experiment, song presentation was randomized. $\boldsymbol{B}$, Simplified sagittal schematic of the ascending avian auditory system. Field L, the primary recipient of auditory information coming from the thalamic nucleus ovoidalis (0v), consists of an interconnected set of subregions (L1, L2a, L2b/L, L3), each of which make connections to secondary nuclei, such as the caudal mesopallium (CM) and the caudomedial nidopallium (NCM). MLd, Mesencephalicus lateralis pars dorsalis. Rostral is left; dorsal is up. $C$, Parasagittal Nissl-stained section from a nonbreeding female. $\boldsymbol{D}$, An adjacent parasagittal section from the same nonbreeding female shown in $\boldsymbol{C}$. Two injections of Fluoro-Ruby were used to reconstruct a single recording track. E, Schematic drawing of the section shown in C. Field L (shaded gray) is bounded dorsally by the hyperpallial lamina (LH) and ventrally by the dorsal medullary lamina (LMD). The magenta circles indicate injection sites. The dashed vertical line shows the reconstruction of a single electrode track that penetrated through field $L$. The black diamonds show the location of individual recording sites along the track. Sections were $40 \mu \mathrm{m}$ thick. Scale bar, $500 \mu \mathrm{m}$. Rostral is left; dorsal is up.

At the end of each recording session, birds were perfused transcardially with ice-cold PBS, followed by $4 \%$ paraformaldehyde. Brains were removed, postfixed in paraformaldehyde, cryoprotected in 30\% sucrose, embedded in gelatin, and postfixed in a $20 \%$ sucrose/ $10 \%$ neutral buffered formalin solution for $48 \mathrm{~h}$. Parasagittal $40 \mu \mathrm{m}$ sections were cut on a freezing microtome and floated in $0.05 \mathrm{M} \mathrm{PB}$. Sections were mounted onto gelatin-subbed slides and processed for Nissl; alternates were air dried until fluorescent or BDA processing.

Sections containing Fluoro-Ruby injections were cleared in xylene, coverslipped in DPX mounting medium (Electron Microscopy Sciences), and dried overnight. Sections containing BDA injections were incubated in 30\% hydrogen peroxide in 100\% methanol, rehydrated in PBS, incubated in ABC (Vector Laboratories), and visualized using DAB (3',3-diaminobenzidine) (Sigma-Aldrich). All images were captured on a Olympus BH2 microscope fitted with a QImaging camera and QCapture software.

Only units that could be localized unambiguously to field L were included in our analyses. It should be noted here that differences in spectrotemporal tuning have been reported for the different subregions of the field L complex (Sen et al., 2001; Nagel and Doupe, 2008; Kim and
Doupe, 2011), raising the possibility that $\mathrm{E}_{2}$ has disparate effects on these different areas. There was insufficient statistical power to allow analysis by subregion, however, as our experimental design already consisted of multiple independent variables. We therefore did not separate our recording sites into anatomical subregions for our analysis.

\section{Hormone measurement}

Immediately before each recording session, we collected blood from the alar wing vein of each bird into a heparinized tube and centrifuged the sample at $4^{\circ} \mathrm{C}$. Separated plasma was stored at $-80^{\circ} \mathrm{C}$ until ELISA. Estradiol levels were measured using a kit (Cayman Chemicals) that had not previously been used with this species, so the assay was first validated as described below.

Multiple controls were used to assess the validity of the kit. First, plasma samples were pooled from multiple sparrows and stripped of steroids by incubating with dextran-coated charcoal in assay buffer (Sigma-Aldrich). This stripped plasma is expected to contain no, or very low levels of estradiol. Second, stripped plasma was spiked with $\mathrm{E}_{2}$ to $3200 \mathrm{pg} / \mathrm{ml}$ and serially diluted. This serial dilution is expected to parallel the standard curve of the kit. Third, raw (unstripped) plasma was divided 
into two samples, one of which was spiked with $1000 \mathrm{pg} / \mathrm{ml}$. These samples are expected to differ in $\mathrm{E}_{2}$ concentration by exactly $1000 \mathrm{pg} / \mathrm{ml}$, and thus is a test of the precision of the kit. Finally, to determine whether lipids or proteins endogenous to white-crowned sparrow plasma interfere with the assay, hormones were extracted from all of the samples outlined above, reconstituted in assay buffer, and assayed separately.

To extract hormones, anhydrous diethyl ether was added to each sample aliquot and vortexed for $1 \mathrm{~min}$. The ether fraction was pipetted into a new test tube, and the extraction was repeated for the remaining plasma layer. Ether fractions were combined for each sample and evaporated under nitrogen gas. Dried, extracted hormone was resuspended in the kit assay buffer and samples were stored at $4^{\circ} \mathrm{C}$ until use.

Results from the validation assay were as expected: stripped plasma contained extremely low levels of estradiol, serial dilutions paralleled the standard curve of the kit, and raw-spiked plasma differed from raw plasma by $\sim 1000 \mathrm{pg} / \mathrm{ml}$. No dramatic differences were observed between extracted samples assayed in buffer and those assayed in raw plasma; therefore, we did not extract hormone from experimental samples and instead assayed the raw plasma directly.

We ran $50 \mu \mathrm{l}$ aliquots of each sample along with eight estrogen standards $(6.6-4000 \mathrm{pg} / \mathrm{ml})$ in a single assay following the protocol of the kit. Some samples were lost during preparation; therefore, only seven samples were assayed for each experimental group. Most samples and all of the kit standards were run in duplicate; however, three samples in each experimental group were run singly because of insufficient sample volume. Briefly, we incubated each sample with $50 \mu \mathrm{l}$ of $\mathrm{E}_{2}$ antiserum and 50 $\mu \mathrm{l}$ of an $\mathrm{E}_{2}$-acetylcholinesterase conjugate for $1 \mathrm{~h}$. After emptying and washing the plate, we added $200 \mu \mathrm{l}$ of enzymatic substrate (Ellman's reagent) to all sample wells. After a $1 \mathrm{~h}$ incubation, we read the plate immediately at $405 \mathrm{~nm}$ on a Dynex MRX II microplate reader.

We plotted the optical densities of the kit standards as a function of known $\mathrm{E}_{2}$ concentration and fit the points with a sigmoid 4PLC equation; sample hormone levels were extrapolated from this standard curve. Intraassay variability was $6.50 \%$.

\section{Statistics}

Monotonic and non-monotonic neurons were analyzed separately. To measure the effect of breeding condition on tone and song-evoked $|\mathrm{RS}|$ values, we set breeding condition as the between-subjects variable and stimulus level as the within-subject variable in two-way repeated-measures mixed-model ANOVAs. For some cells, we had an incomplete dataset, such that a given stimulus (tone or song) was only presented for a limited range of intensities. These missing values presented an obstacle for running a repeated-measures ANOVA. We therefore performed each ANOVA twice: In one version, we included all the cells in the dataset and discarded any stimulus level with missing values. In the other version, we discarded any cells that had missing values and included all the stimulus levels. Both of these versions gave similar results; therefore, we report here only the results obtained when all cells were included in the ANOVAs.

We used a Mann-Whitney $U$ test to compare $\mathrm{E}_{2}$ levels across experimental conditions. All correlations (between song and tone thresholds or between hormone levels and firing rates) were assessed with Pearson's $r$. For the remainder of our analyses, we indicate which statistical tests were used in table legends, or in Results, when appropriate. Unless otherwise stated, all values are reported as means \pm SEMs. All statistical analyses were made using PASW Statistics 18.0 or GraphPad Prism.

\section{Results}

\section{Plasma $\mathrm{E}_{2}$ levels}

Females housed under breeding $\left(\mathrm{LD}+\mathrm{E}_{2}\right)$ condition had elevated levels of plasma $\mathrm{E}_{2}$ compared with females housed under nonbreeding (SD) condition $(397.8 \pm 187.5$ vs $26.3 \pm 8.13 \mathrm{pg} / \mathrm{ml}$; Mann-Whitney $\left.U=1.000 ; n_{1}=n_{2}=7 ; p=0.003\right)$. Plasma $\mathrm{E}_{2}$ levels in birds housed under breeding condition were similar to the physiological range reported by Wingfield and Farner (1978) for wild breeding female white-crowned sparrows $(\sim 300-500$ $\mathrm{pg} / \mathrm{ml})$.
Table 1. Auditory-responsive cells in field L

\begin{tabular}{lrc}
\hline & Breeding & Nonbreeding \\
\hline No. total responsive cells & $30^{a}(9)$ & $47(12)$ \\
No. total song responses & $21(8)$ & $37(11)$ \\
No. total tone responses & $24(9)$ & $29(10)$ \\
Only song response & $6(5)$ & $18(9)$ \\
Only tone response & $9(7)$ & $10(5)$ \\
Monotonic & $3(3)$ & $9(5)$ \\
Non-monotonic & $6(5)$ & $1(1)$ \\
Both tone and song response & $15^{a}(6)$ & $19(8)$ \\
Monotonic & $9(6)$ & $7(5)$ \\
Non-monotonic & $6^{a}(3)$ & $12(7)$ \\
\hline
\end{tabular}

Values are number of cells; numbers in parentheses indicate number of animals.

${ }^{a}$ Value excludes an outlier that was removed from the dataset. For explanation of response breakdown, see Results.

\section{Auditory responses of field $\mathrm{L}$ neurons}

We recorded from a total of 77 auditory-responsive cells histologically confirmed to be in field L (Fig. 1C-E). Of these, 30 auditory cells were recorded from 9 birds in breeding condition and 47 cells were recorded from 12 birds in nonbreeding condition (Table 1). For some cells, we were only able to record song responses (either because the cell was unresponsive to tones, or because we could not hold the isolation long enough to record a full tone response area). Similarly, in another subset of cells, we were only able to record tone responses. We were able to record both song and tone responses in a final subset of cells.

\section{Tone responses}

Tone responses can be monotonic or non-monotonic

Tone-responsive neurons in field $\mathrm{L}$ can be categorized as monotonic or non-monotonic, based on the shape of their rate level function. Monotonic neurons increase their firing rate with increasing stimulus intensities (Fig. 2A,C). Conversely, the firing rate of non-monotonic neurons increases up to some midlevel stimulus intensity before decreasing at higher intensities (Fig. $2 B, D)$.

We calculated a MI for each neuron to determine whether monotonic and non-monotonic cells were two separate populations. The results of this analysis are shown in Figure $2 E$. While there is a small amount of overlap between the two groups, the distributions clearly segregate from one another. Only 3 of 25 neurons classified as non-monotonic have MIs $>0.70$. Each of these neurons had classic "inverted V"-shaped rate level functions, up through $80 \mathrm{~dB}$ SPL. At $90 \mathrm{~dB}$ SPL, each of these cells showed an increase in activity, such that their overall rate level function was "N" shaped. This "N" shape accounted for the high MI values in these cells. If the MI was instead calculated using 80 $\mathrm{dB}$ SPL as the maximum stimulus amplitude, each of these cells showed values of $\mathrm{MI}<0.70$.

Similarly, only 2 of 28 cells that were classified as monotonic had values of MI $<0.70$. Both of these cells showed rate level functions that saturated at midlevel intensities, with a small decrease in firing rate at $90 \mathrm{~dB}$ SPL. This decrease, although not large enough for us to classify the cells as non-monotonic, accounts for the lower MI values.

When we compared the groups using a two-sample $t$ test, we found that monotonic neurons had significantly higher MIs than non-monotonic neurons $\left(0.887 \pm 0.025\right.$ vs $0.410 \pm 0.054 ; t_{(51)}=$ 8.331; $p<0.001)$. Together, these findings suggest that the monotonic and non-monotonic cells we report on here likely comprise two distinct populations of neurons.

Monotonic $(n=28)$ and non-monotonic $(n=25)$ cells were equally abundant in field $\mathrm{L}$, and breeding condition had no effect 
A Monotonic

\section{0}
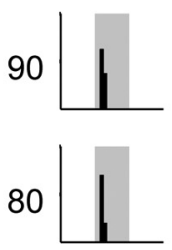

$70 \mid$
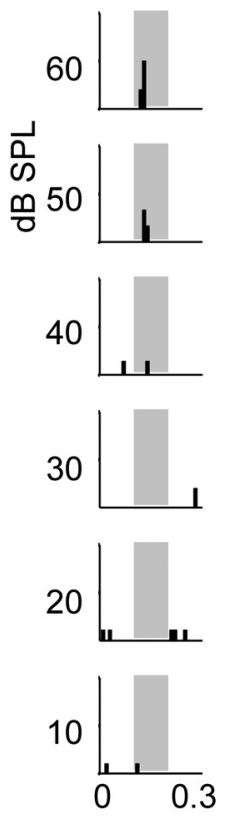
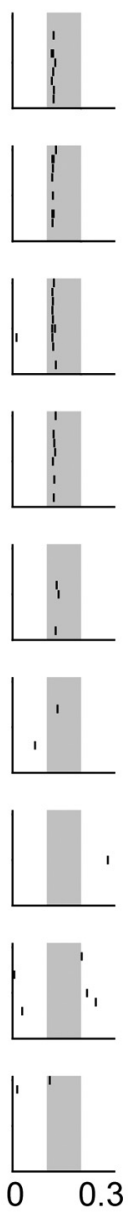

$\mathrm{sec}$
B Non-Monotonic
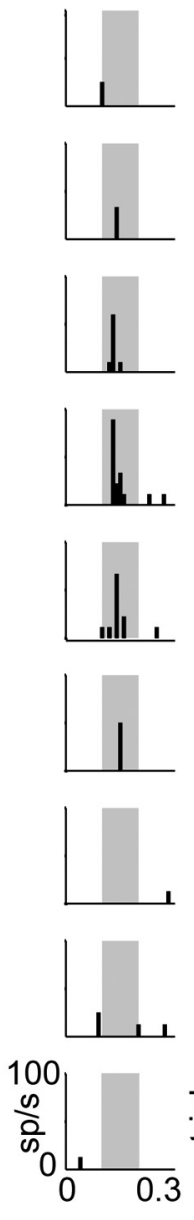

sec
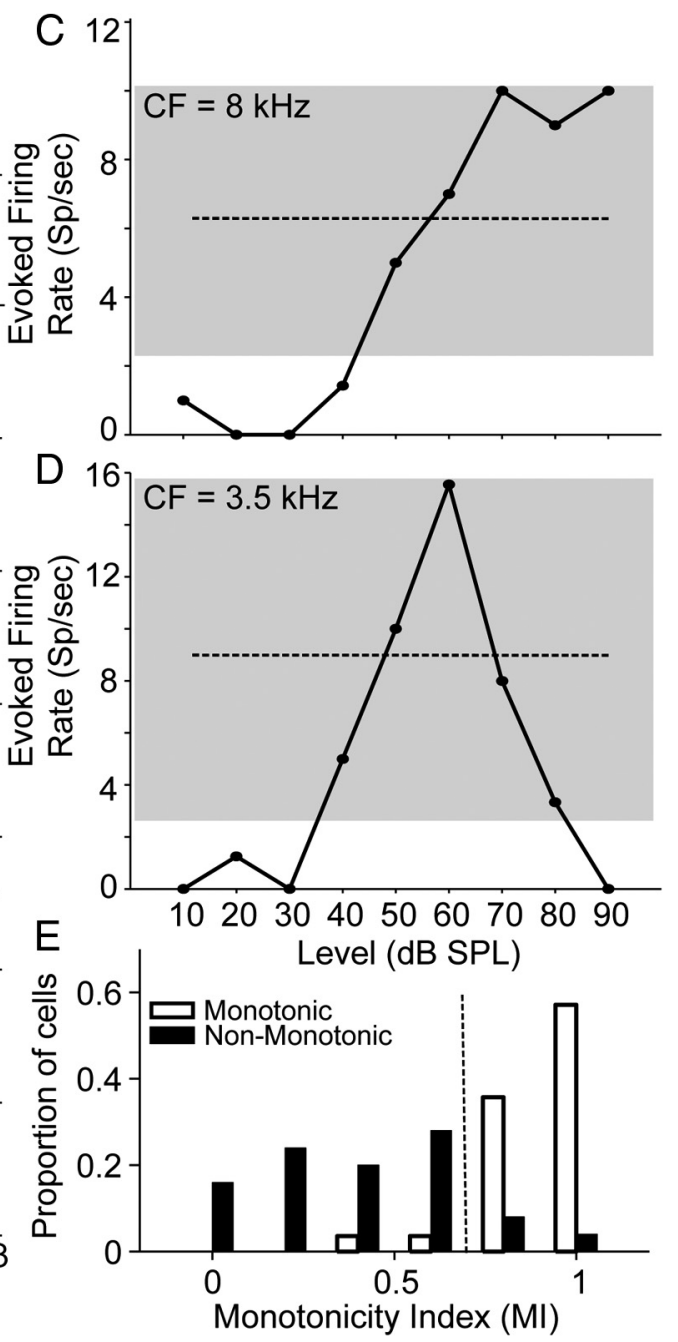

Figure 2. Field L contains monotonic and non-monotonic neurons. $A$, Representative PSTH (left) and raster plots (right) from an individual monotonic neuron in a nonbreeding female. Plots were generated in response to 10 presentations of the characteristic frequency of the neuron ( $8 \mathrm{kHz}$ ) and are arranged in rows by decreasing tone intensity (indicated by decibel SPL values on the left). The $x$-axis for each panel shows time (in seconds) as indicated on the bottom row of panels. The $y$-axis for each PSTH panel is the firing rate of the neuron in spikes per second; the $y$-axis for each raster panel indicates the trial number. For clarity, only the bottom-most panels in $\boldsymbol{B}$ have $y$-axis labels. Stimulus presentations are indicated by gray-shaded regions. $\boldsymbol{B}$, Representative raster and PSTH plots from an individual non-monotonic neuron in a breeding female. Characteristic frequency was $3.5 \mathrm{kHz}$. Plot conventions and labeling are as in $\boldsymbol{A}$. $C$, The rate level function for the neuron shown in $\boldsymbol{A}$. The gray-shaded region highlights the firing rate range of the neuron (spikes per second). The dashed line is the halfway (50\%) point between the maximum firing rate of the neuron and the noise floor (2 SDs above the spontaneous rate) and is the cutoff point for determining whether a neuron is monotonic or non-monotonic. The evoked firing rate of this neuron increases with increasing tone intensity and reaches a maximum firing rate at $70 \mathrm{dBSPL}$. As the firing rate of this neuron remained elevated at higher intensities, and never dropped below the $50 \%$ boundary, it was classified as monotonic. $\boldsymbol{D}$, The rate level function for the neuron shown in $\boldsymbol{B}$. This neuron only increased its evoked firing rate to midlevel tone presentations ( $50-70 \mathrm{~dB} S \mathrm{PL})$. After reaching its maximum rate at $60 \mathrm{~dB} \mathrm{SPL}$, the firing rate of the neuron drops below $50 \%$ of the firing rate range. This neuron was therefore classified as non-monotonic. Plot conventions are as in $C$. $E$, Group histograms for monotonic (white) and non-monotonic (black) neurons showing the proportion of cells with various Mls. Increasing Ml values represent increasing degrees of monotonicity. The majority of monotonic neurons have values of $\mathrm{Ml}>0.70$ (dotted vertical line), while the majority of non-monotonic neurons have values of $\mathrm{Ml}<0.70$. The number of cells and the number of birds (in parentheses) are as follows: monotonic neurons, 28 (16); non-monotonic neurons, 25 (13).

on their relative proportions. Similarly, spike half-widths of monotonic and non-monotonic neurons remained stable across breeding conditions. These results are presented in more detail with their accompanying statistics in Table 2.

The anatomical positions of monotonic and non-monotonic neurons did not differ across the anterior-posterior and dorsalventral extents of field L. Individual recording sites overlapped along both the rostral-caudal and dorsal-ventral axes (Fig. 3), and breeding condition had no effect on the spatial distribution of monotonic or non-monotonic neurons (Table 2).

\section{Breeding condition does not affect CF distributions or} frequency tuning

Tone-responsive neurons in the avian auditory forebrain are tuned to specific frequencies arranged in a topographic manner
(Müller and Leppelsack, 1985; Wild et al., 1993). We investigated whether the CF distributions for monotonic and non-monotonic neurons differed between breeding conditions. Breeding condition had no effect on the distribution of characteristic frequencies in monotonic or non-monotonic neurons. We also quantified tuning precision by calculating frequency bandwidths $10 \mathrm{~dB}$ above the best threshold of each neuron. No effect of breeding condition was observed on frequency bandwidths for monotonic or non-monotonic cells. Detailed results and accompanying statistics can be found in Table 2 .

Breeding condition increases spontaneous and maximum firing rates in monotonic neurons

Previous work has suggested that $\mathrm{E}_{2}$ increases neuronal responsiveness in NCM, a secondary region of the songbird auditory 
Table 2. Properties of cells under breeding and nonbreeding conditions

\begin{tabular}{|c|c|c|c|c|}
\hline & Breeding & Nonbreeding & Effect of breeding condition & \\
\hline \multicolumn{5}{|l|}{ Monotonic neurons } \\
\hline Spike half-width (ms) & $0.154 \pm 0.045$ & $0.154 \pm 0.038$ & $F_{(1,26)}=0.002$ & $p=0.968$ \\
\hline $10 \mathrm{~dB}$ bandwidth $(\mathrm{kHz})$ & $1.55 \pm 0.78$ & $1.65 \pm 0.82$ & $F_{(1,26)}=0.107$ & $p=0.746$ \\
\hline Mean $\mathrm{CF}(\mathrm{kHz})$ & $3.93 \pm 1.82$ & $3.78 \pm 2.15$ & $F_{(1,26)}=0.037$ & $p=0.849$ \\
\hline Mean recording depth $(\mathrm{mm})$ & $2.377 \pm 0.368$ & $2.270 \pm 0.388$ & $F_{(1,26)}^{(1,20)}=0.548$ & $p=0.466$ \\
\hline Number (percentage of monotonic cells) & $12(43 \%)$ & $16(57 \%)$ & $\chi_{(1, N=28)}^{2}=0.571$ & $p=0.450$ \\
\hline \multicolumn{5}{|l|}{ Non-monotonic neurons } \\
\hline Spike half-width (ms) & $0.167 \pm 0.062$ & $0.172 \pm 0.052$ & $F_{(1,23)}=0.044$ & $p=0.836$ \\
\hline $10 \mathrm{~dB}$ bandwidth $(\mathrm{kHz})$ & $1.30 \pm 0.56$ & $1.16 \pm 0.49$ & $F_{(1,17)}=0.308$ & $p=0.586$ \\
\hline Mean $\mathrm{CF}(\mathrm{kHz})$ & $4.53 \pm 2.00$ & $4.53 \pm 2.05$ & $F_{(1,23)}=0.000$ & $p=0.994$ \\
\hline Mean recording depth & $2.427 \pm 0.421$ & $2.338 \pm 0.345$ & $F_{(1,23)}=0.334$ & $p=0.569$ \\
\hline Number (percentage of non-monotonic cells) & $12(48 \%)$ & $13(52) \%$ & $\chi_{(1, N=25)}^{2}=0.040$ & $p=0.841$ \\
\hline
\end{tabular}

Values are means \pm SDs, unless otherwise noted. Spike half-width, $10 \mathrm{~dB}$ bandwidth, mean $\mathrm{CF}$, and mean recording depth were assessed with one-way ANOVAs. The relative numbers of cells under each condition were assessed with Pearson's $\chi^{2}$ test.
- Breeding Monotonic
$\mathrm{n}=12(7)$
- Non-Breeding Monotonic
$\mathrm{n}=16(9)$
$\Delta$ Breeding Non-Monotonic
$n=12(6)$
$\Delta$ Non-Breeding Non-Monotonic $n=13(7)$

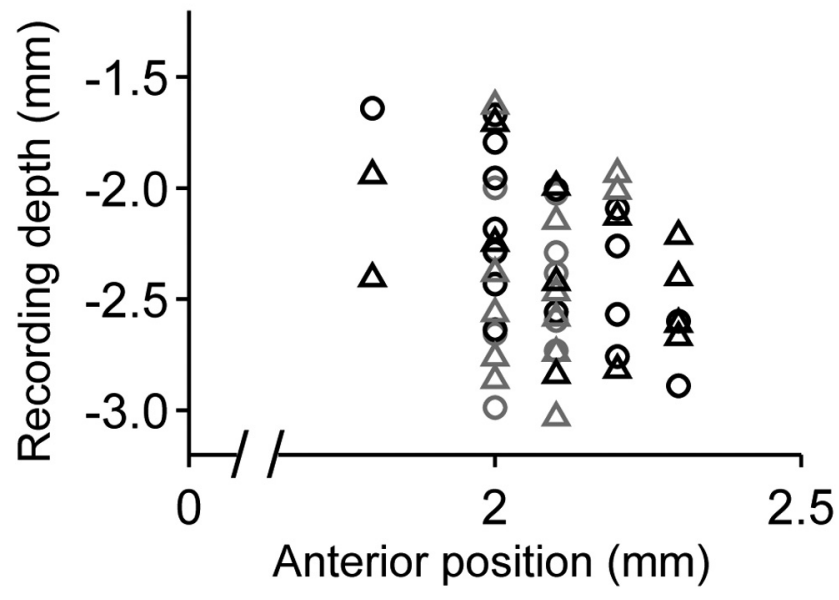

Figure 3. Breeding condition does not affect the spatial distribution of monotonic and nonmonotonic neurons. The anatomical location of individual tone responsive neurons are plotted as a function of recording depth and anterior distance from the bifurcation of the midsagittal sinus. Breeding (gray) and nonbreeding (black) monotonic (circles) and non-monotonic (triangles) neurons are evenly distributed across the anterior-posterior and dorsal-ventral extents of field $L$. Because the vast majority of neurons were recorded from the same medial-lateral position, all tone-responsive neurons are plotted within a single sagittal plane. Sample sizes for each group are the number of cells, followed by the number of birds in parentheses.

forebrain that expresses estrogen receptors (ERs) (Tremere et al., 2009; Maney and Pinaud, 2011; Tremere and Pinaud, 2011) (Fig. $1 B)$. To determine whether $\mathrm{E}_{2}$ has similar effects on field $\mathrm{L}$ neurons, a region that does not express steroid receptors, we calculated average spontaneous and maximum evoked firing rates from cells in birds under different breeding conditions (Fig. 4). $\mathrm{E}_{2}$ treatment significantly increased spontaneous firing rates of monotonic neurons. Similarly, monotonic cells showed a trend toward an increase in maximum evoked firing rates at CF. Spontaneous and maximum firing rates increased by the same relative amount, however, such that the firing rate range of these cells remained constant across breeding and nonbreeding conditions. Table 3 provides the statistical results of these comparisons.

Figure 4 also illustrates that $\mathrm{E}_{2}$ had different effects on nonmonotonic neurons. While breeding condition did not have a significant effect on spontaneous firing rates of non- monotonic neurons, $\mathrm{E}_{2}$ treatment significantly decreased maximum evoked firing rates of these cells. This combination resulted in a significant decrease in the firing rate range of non-monotonic neurons. The associated statistics for these comparisons are listed in Table 3.

Breeding condition increases tone-evoked response strength and sensitivity of monotonic neurons

The effects of $E_{2}$ on maximum evoked firing rates could be explained by an overall shift in evoked firing rates across stimulus levels, and/or a change in the shape of the rate level function, both of which could give rise to changes in auditory thresholds and dynamic ranges. To address this issue, we calculated RS level functions at CF for monotonic and non-monotonic neurons under different breeding conditions.

Figure $5 A$ shows group RS data for monotonic neurons across stimulus level; accompanying statistical results are listed in Table 4. Input-output functions had similar shapes across experimental conditions, peaking at $80 \mathrm{~dB}$ SPL under breeding condition and $90 \mathrm{~dB}$ SPL under nonbreeding condition. The effect of sound intensity was significant. In addition, breeding condition significantly increased monotonic tone RS values across levels, by an average of $9.08 \mathrm{sp} / \mathrm{s}$. The interaction between breeding condition and tone intensity on monotonic tone RS was also significant, such that the largest differences between the experimental groups occurred at midlevel intensities. Table 4 shows the accompanying statistics for this analysis.

The effect of breeding condition on overall response magnitude resulted in differences in auditory sensitivity. Breeding condition significantly lowered CF thresholds compared with nonbreeding condition in monotonic cells (Fig. 5C). The $\mathrm{E}_{2}$ induced decrease in threshold contributed to a slight, but nonsignificant increase in monotonic neuron dynamic range (Fig. $5 E$ ). The statistics for these comparisons can be found in Table 3.

Figure $5 B$ shows group RS data for non-monotonic neurons across stimulus level. As above, input-output functions for breeding and nonbreeding groups had similar shapes, peaking at 60 and $50 \mathrm{~dB}$ SPL, respectively, and the overall effect of sound level was significant. In contrast to the monotonic neurons, breeding condition significantly decreased tone RS values in nonmonotonic neurons across stimulus levels by an average of 5.76 $\mathrm{sp} / \mathrm{s}$. The interaction term between level and breeding condition was not significant and no effect was found on CF threshold (Fig. $5 D$ ) or on dynamic ranges (Fig. 5F) in these cells. The results of these statistical analyses can be found in Tables 3 and 4 .

To summarize the preceding results, breeding condition increased spontaneous firing rates, maximum evoked firing rates, 
A
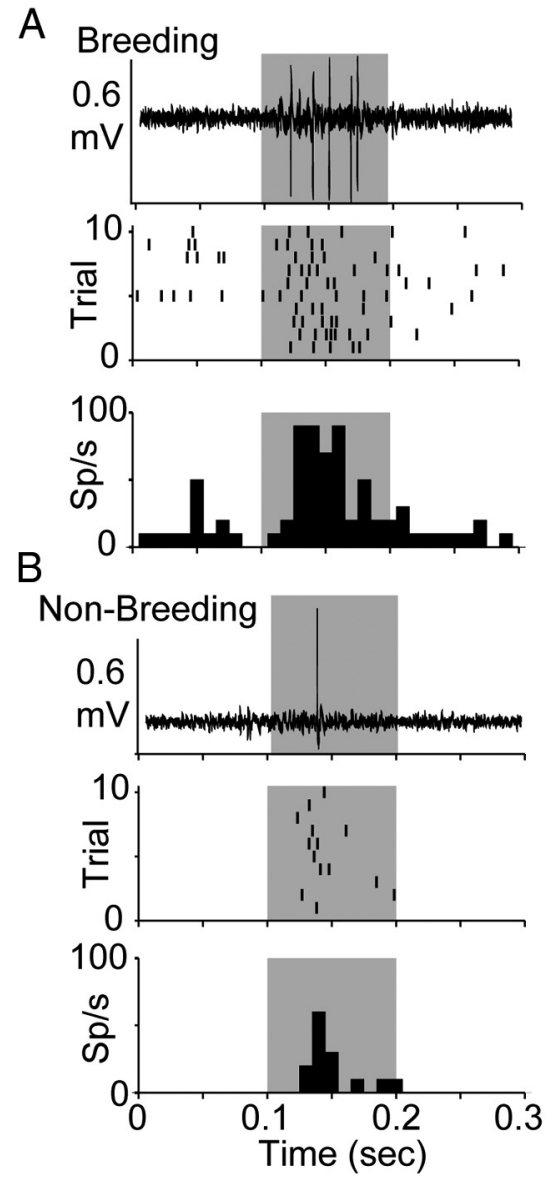
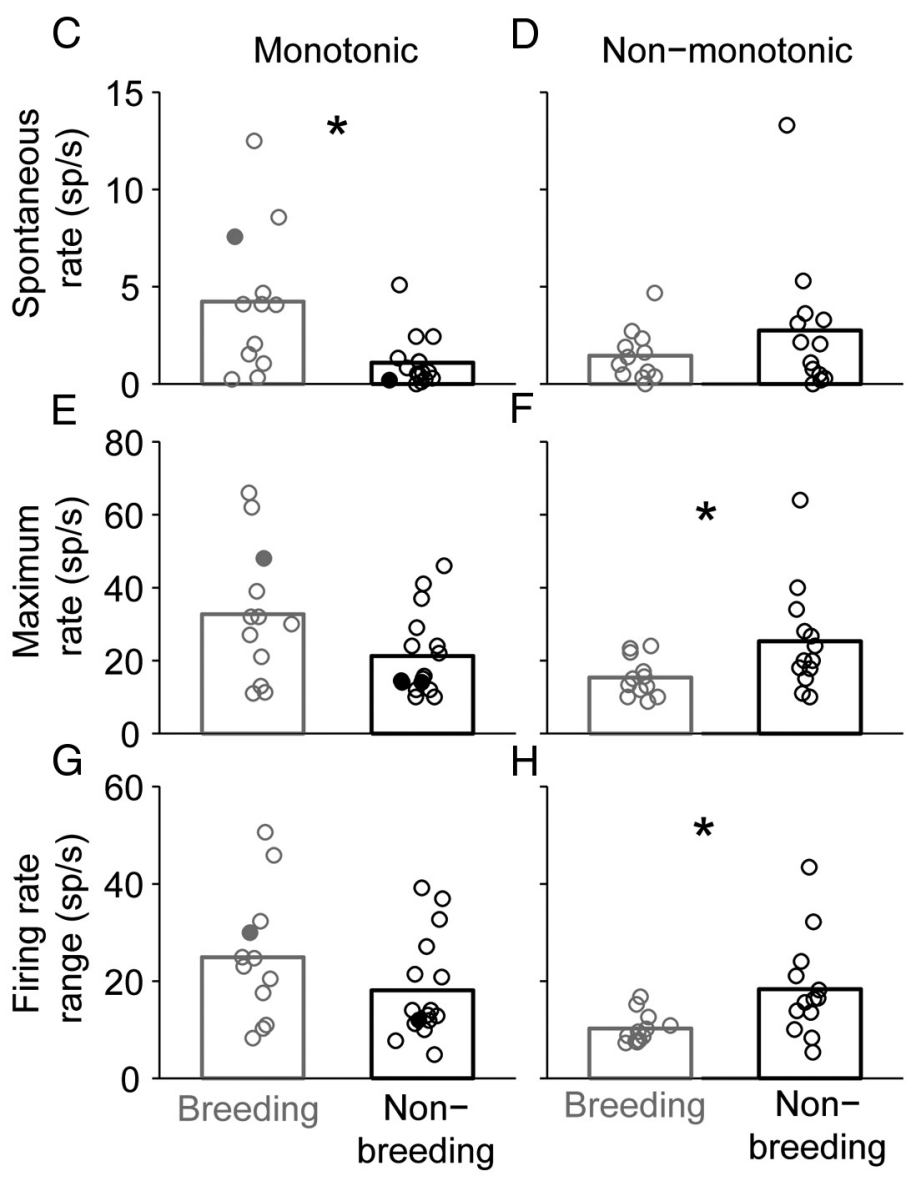

Figure 4. Breeding condition modulates activity in a cell-specific manner. $\boldsymbol{A}$, Representative raw trace (top), raster (middle), and PSTH (bottom) recorded from an individual monotonic neuron in a breeding female. Raster and PSTH plots were generated in response to 10 presentations of the CF of the neuron ( $2.2 \mathrm{kHz})$ at the stimulus intensity that elicited the maximum firing rate of the neuron ( $80 \mathrm{dBSPL}$ ). The single raw trace shows the response to the first presentation of the CF (identical to the bottom row of the raster). Stimulus presentation is indicated by the gray-shaded region. This neuron is indicated in $\boldsymbol{C}, \boldsymbol{E}$, and $\boldsymbol{G}$ as the filled gray circle. $\boldsymbol{B}$, Representative example from an individual monotonic neuron in a nonbreeding female. $\boldsymbol{C F}$ was $1.6 \mathrm{kHz}$; the intensity that elicited the maximum rate was $70 \mathrm{~dB}$ SPL. Plot conventions are as in $\boldsymbol{A}$. This neuron is represented in $\boldsymbol{C}, \boldsymbol{E}$, and $\boldsymbol{G}$ as the filled black circle. $\boldsymbol{C}, \boldsymbol{D}$, Breeding condition (gray) significantly increases spontaneous firing rates compared with nonbreeding condition (black) in monotonic neurons $(\boldsymbol{C}$ ), but does not significantly affect spontaneous firing rates in non-monotonic neurons $(\boldsymbol{D})$. $\boldsymbol{E}, \boldsymbol{F}$, Breeding condition marginally increases (F-evoked maximum firing rates in monotonic neurons $(\boldsymbol{E})$, but significantly decreases maximum firing rates in non-monotonic neurons $(\boldsymbol{F})$. $\boldsymbol{G}, \boldsymbol{H}$, Breeding condition does not significantly affect $\mathrm{CF}$-evoked firing rate ranges in monotonic neurons $(\boldsymbol{G})$, but significantly decreases firing rate ranges in non-monotonic neurons $(\boldsymbol{H})$. The bars in $\boldsymbol{C}-\boldsymbol{H}$ are means; the circles represent individual neurons. The asterisks indicate statistical significance ( $p<0.05)$. The number of cells and the number of birds (in parentheses) are as follows: monotonic neurons: breeding, 12 (7); nonbreeding, 16 (9); non-monotonic neurons: breeding, 12 (6); nonbreeding, 13 (7).

tone-evoked response strengths, and pure-tone sensitivity in monotonic, but not non-monotonic neurons.

\section{Song responses of field $\mathrm{L}$ neurons}

Song responses can be excitatory or suppressive

Previous work has shown an effect of $\mathrm{E}_{2}$ treatment on selectivity and discrimination of conspecific song stimuli in secondary auditory forebrain regions (Maney et al., 2006; Tremere et al., 2009; Remage-Healey et al., 2010, 2012; Sanford et al., 2010; Tremere and Pinaud, 2011; Remage-Healey and Joshi, 2012). All of these studies presented song at a single intensity level, however. Therefore, before determining whether $\mathrm{E}_{2}$ affects field $\mathrm{L}$ song response properties, we first examined song-evoked rate level functions in individual cells. We observed that, while the majority ( 40 of 58) of responses to conspecific song were excitatory (Fig. 6A,C), increasing their rate as a function of song level, a substantial portion of them (18 of 58) were suppressive (Fig. $6 B, D$ ). Breeding condition did not influence the relative proportions of excitatory or suppressive song responses in field L (Table 5). To determine whether breeding condition affects song-evoked excitability, we calculated the maximum song-evoked $|\mathrm{RS}|$ for each cell; we found no effect of breeding condition (Table 5).

Breeding condition increases song-evoked response strength and dynamic range of cells with monotonic tone responses

We used the absolute value of response strength $(|\mathrm{RS}|)$ to analyze the change in neuronal firing rate for all song responses together. Song $|\mathrm{RS}|$ values increased as a function of song level in both breeding and nonbreeding groups $\left(F_{(4,56)}=14.46 ; p<0.001\right)$. $\mathrm{E}_{2}$ treatment, however, did not significantly affect rate level shapes or magnitudes $\left(F_{(1,56)}=0.075 ; p=0.785\right)$, and no interaction between breeding condition and song level was observed $\left(F_{(4,56)}=\right.$ $0.313 ; p=0.870)$. As noted in Table 5 , breeding and nonbreeding groups also had similar song thresholds and dynamic ranges.

Thus, our results show that, when all neurons in our sample are considered, $\mathrm{E}_{2}$ treatment has no effect on song responses. Given that $\mathrm{E}_{2}$ treatment modulated tone responses in a selective manner, however, we analyzed song responses separately for different classes of neurons.

Tone and song thresholds were correlated within individual cells for both breeding $(r=0.60 ; n=15 ; p=0.019)$ and non- 
Table 3. Statistics for neurons under breeding and nonbreeding conditions

\begin{tabular}{lll}
\hline & Effect of breeding condition & \\
\hline Monotonic neurons & & \\
Spontaneous rate (sp/s) & $F_{(1,26)}=9.932$ & $p=0.004$ \\
Maximum evoked rate (sp/s) & $F_{(1,26)}=4.078$ & $p=0.054$ \\
Firing rate range (sp/s) & $F_{(1,26)}=2.274$ & $p=0.144$ \\
CF threshold (dB SPL) & $F_{(1,26)}=4.788$ & $p=0.038$ \\
CF dynamic range (dB SPL) & $F_{(1,26)}=2.979$ & $p=0.096$ \\
Song threshold (dB SPL) & $F_{(1,14)}=0.732$ & $p=0.407$ \\
Song dynamic range (dB SPL) & $F_{(1,14)}=4.212$ & $p=0.059$ \\
Non-monotonic neurons & & \\
Spontaneous rate (sp/s) & $F_{(1,23)}=1.388$ & $p=0.251$ \\
Maximum evoked rate (sp/s) & $F_{(1,23)}=5.001$ & $p=0.035$ \\
Firing rate range (sp/s) & $F_{(1,23)}=6.926$ & $p=0.015$ \\
CF threshold (dB SPL) & $F_{(1,23)}=1.118$ & $p=0.301$ \\
CF dynamic range (dB SPL) & $F_{(1,23)}=1.135$ & $p=0.298$ \\
Song threshold (dB SPL) & $F_{(1,16)}=0.482$ & $p=0.497$ \\
Song dynamic range (dB SPL) & $F_{(1,16)}=1.623$ & $p=0.221$ \\
\hline
\end{tabular}

Three separate MANOVAs were performed on each cell population (monotonic and non-monotonic): One encompassed spontaneous rate, maximum evoked rate, and firing rate range. Another included $C F$ threshold and $C F$ dynamic range. The third included song threshold and song dynamic range. Individual $F$ statistics and associated $p$ values indicating the effect of breeding condition are reported here.

breeding ( $r=0.61 ; n=19 ; p=0.006)$ groups (Fig. 7). Song thresholds were higher than tone thresholds. This finding is not surprising, given that tone thresholds were measured at $\mathrm{CF}$, the optimal tonal stimulus of the unit.

The correlation between song and tone thresholds led us to predict that $\mathrm{E}_{2}$ treatment enhances song responses, but only in neurons with monotonic input-output functions in response to pure-tone stimuli. To examine this issue, we examined songevoked $|\mathrm{RS}|$ level functions separately for cells that had monotonic and non-monotonic tone input-output functions. For cells that had monotonic tone responses, there was a significant effect of sound intensity on average song-evoked $|\mathrm{RS}|$ values under both breeding and nonbreeding conditions (Fig. 8A). $\mathrm{E}_{2}$ treatment significantly increased song-evoked $|\mathrm{RS}|$ values in these cells by an average of $2.578 \mathrm{sp} / \mathrm{s}$ across levels. Importantly, there was a significant interaction between song intensity and breeding condition; while breeding condition had a small impact at even at the lowest intensity tested, this effect became more pronounced as song intensity increased. The greatest difference between conditions was observed at $90 \mathrm{~dB}$ SPL. Because the greatest shift in the input-output function occurred at higher stimulus levels, there was no significant change in song threshold (Fig. 8C). In addition, there was a trend for breeding condition to increase song dynamic range in cells with monotonic tone responses (Fig. 8E), but this trend failed to achieve statistical significance. The results of these statistical analyses can be found in Tables 3 and 4 .

Average song-evoked $|\mathrm{RS}|$ values are plotted as a function of sound level for cells that had non-monotonic tone responses in Figure $8 B$. In these cells, the effect of level was not significant. $\mathrm{E}_{2}$ treatment did not significantly alter $|\mathrm{RS}|$ values across sound intensity, nor was there a significant interaction between song intensity and breeding condition (Table 4). Finally, breeding condition did not have a significant effect on song thresholds (Fig. $8 D$ ) or song dynamic ranges (Fig. $8 F$ ) in cells that had non-monotonic tone responses (see Table 3 for associated statistics).

In summary, breeding condition increased song-evoked response strengths and dynamic ranges in neurons with monotonic tone responses, but not neurons with non-monotonic tone responses.
A

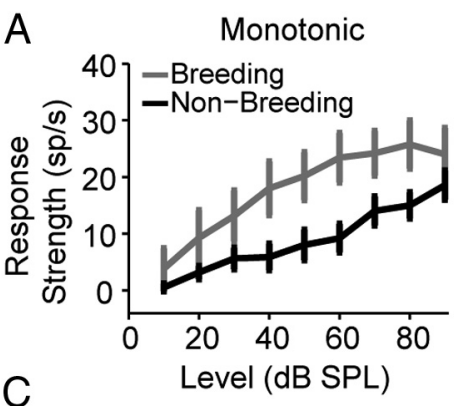

B Non-Monotonic
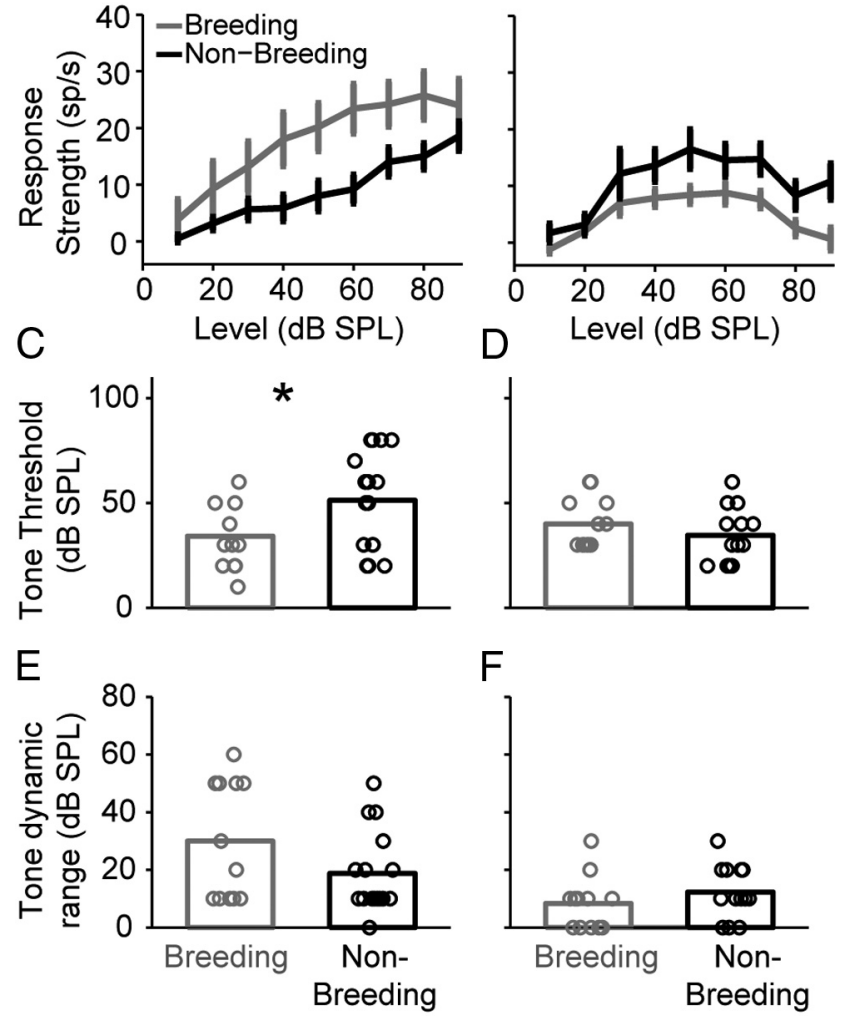

Figure 5. Breeding condition selectively increases tone-evoked response strength and sensitivity in monotonically driven neurons. $\boldsymbol{A}, \boldsymbol{B}$, Breeding condition (gray) significantly increases (F-evoked response strengths compared with nonbreeding condition (black) in monotonic neurons $(\boldsymbol{A})$, but decreases $(\mathrm{F}$-evoked response strengths in non-monotonic neurons $(\boldsymbol{B}) . \boldsymbol{C}, \boldsymbol{D}$, Breeding condition selectively decreases (F-evoked thresholds in monotonic neurons ( $\boldsymbol{C}$, but does not significantly affect $(F$ thresholds in non-monotonic neurons (D). E, F, Breeding condition does not significantly affect $(F$ dynamic ranges in monotonic neurons $(\boldsymbol{E})$, or nonmonotonic neurons $(\boldsymbol{F})$. Data in $\boldsymbol{A}$ and $\boldsymbol{B}$ are means \pm SEMs. The bars in $\boldsymbol{C}-\boldsymbol{F}$ are means; the circles represent individual neurons. The asterisks indicate statistical significance $(p<0.05)$. The number of cells and the number of birds (in parentheses) are as follows: monotonic neurons: breeding, 12 (7); nonbreeding, 16 (9), except at $90 \mathrm{~dB} \mathrm{SPL}$ in A; monotonic breeding, 11 (7). Sample sizes for non-monotonic neurons are as follows: breeding, 12 (6); nonbreeding, 13 (7), except at $90 \mathrm{~dB}$ SPL in $\boldsymbol{B}$; non-monotonic breeding, 10 (5).

\section{Plasma $\mathrm{E}_{2}$ concentrations predict firing rates and response strengths}

The observations that breeding condition influenced auditory response properties in a select subset of field L neurons (Figs. 4, 5, 8) led us to ask whether plasma $E_{2}$ concentrations in individual birds correlate with single-unit firing rates or response strengths. To address this question, we compared the response properties of neurons from individual animals with the circulating level of plasma $E_{2}$. As shown in Figure 9, plasma $E_{2}$ concentrations were positively and significantly correlated with spontaneous firing rates $(r=0.71 ; n=18 ; p<0.001)$ and maximum evoked firing rates $(r=0.66 ; n=18 ; p=0.003)$ of monotonic neurons (Fig. $9 A$ ). Plasma $\mathrm{E}_{2}$ concentrations did not correlate with either spontaneous or evoked firing rates in non-monotonic cells (Fig. 9B). Similarly, while systemic $\mathrm{E}_{2}$ levels positively predicted both toneevoked (Fig. 9C) and song-evoked (Fig. 9D) response strengths in cells with monotonic rate level functions to pure tones, there was no correlation between $E_{2}$ and response strengths in cells with non-monotonic tone rate level functions (Fig. 9E,F). The response strengths shown in Figure $9 C-F$ were all elicited at $50 \mathrm{~dB}$ 
Table 4. Effects of breeding condition and sound level on tone RS and song $|R S|$ values for monotonic and non-monotonic neurons

\begin{tabular}{|c|c|c|c|c|c|c|}
\hline \multirow{2}{*}{ Monotonic } & \multicolumn{2}{|c|}{ Effect of breeding condition } & \multicolumn{2}{|c|}{ Effect of sound level } & \multicolumn{2}{|c|}{ Breeding condition by level interaction } \\
\hline & & & & & & \\
\hline Tone RS & $F_{(1,26)}=6.082$ & $p=0.021$ & $F_{(7,26)}=28.14$ & $p<0.001$ & $F_{(7,26)}=2.329$ & $p=0.027$ \\
\hline Song $|\mathrm{RS}|$ & $F_{(1,14)}=4.879$ & $p=0.044$ & $F_{(5,14)}=12.13$ & $p<0.001$ & $F_{(5,14)}=3.020$ & $p=0.016$ \\
\hline \multicolumn{7}{|c|}{ Non-monotonic } \\
\hline Tone RS & $F_{(1,23)}=5.269$ & $p=0.031$ & $F_{(7,23)}=12.01$ & $p<0.001$ & $F_{(7,23)}=0.692$ & $p=0.679$ \\
\hline Song $|\mathrm{RS}|$ & $F_{(1,16)}=1.087$ & $p=0.313$ & $F_{(4,16)}=2.039$ & $p=0.099$ & $F_{(4,16)}=1.175$ & $p=0.330$ \\
\hline
\end{tabular}

Four separate two-way (condition by level) mixed-model ANOVAs were performed. Breeding condition was the between-subject measure; sound level was the repeated-subject measure. The values listed in each row are the result of a single ANOVA.

A

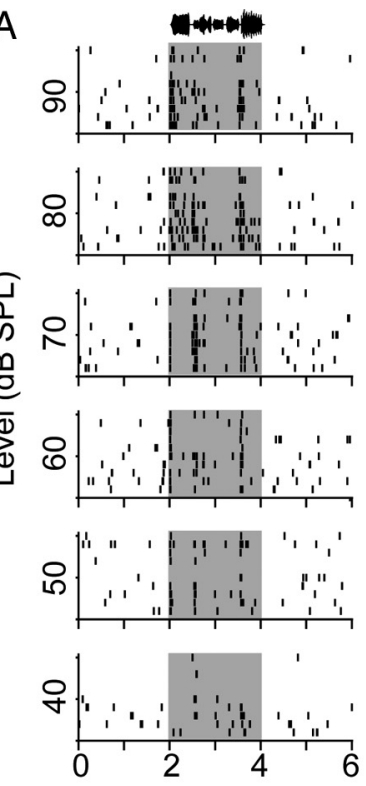

B

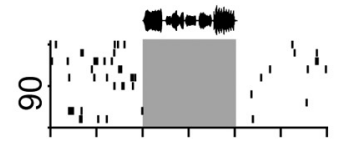

Time (s)
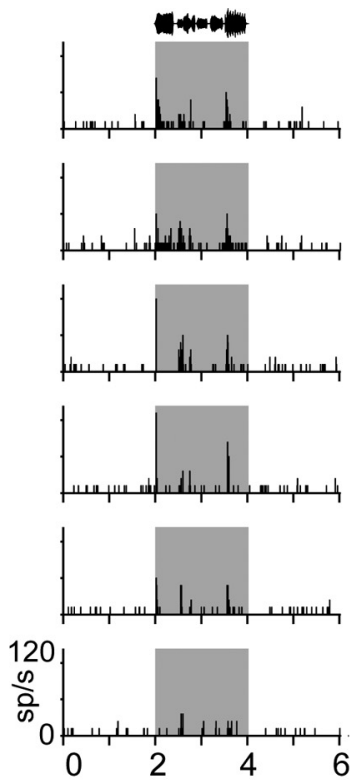

$$
\text { (s) }
$$
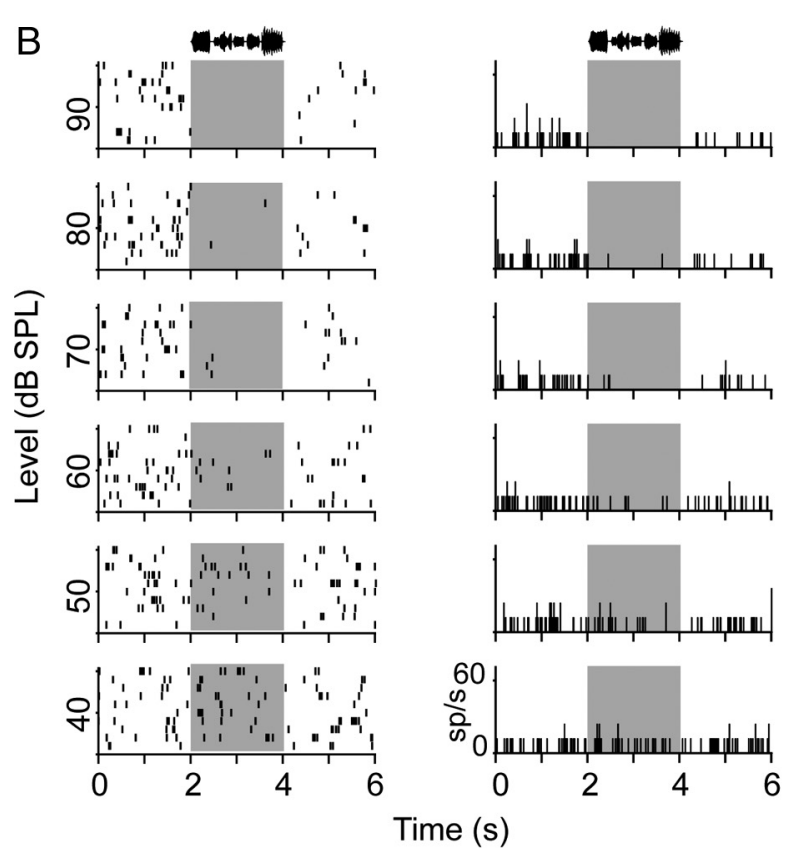
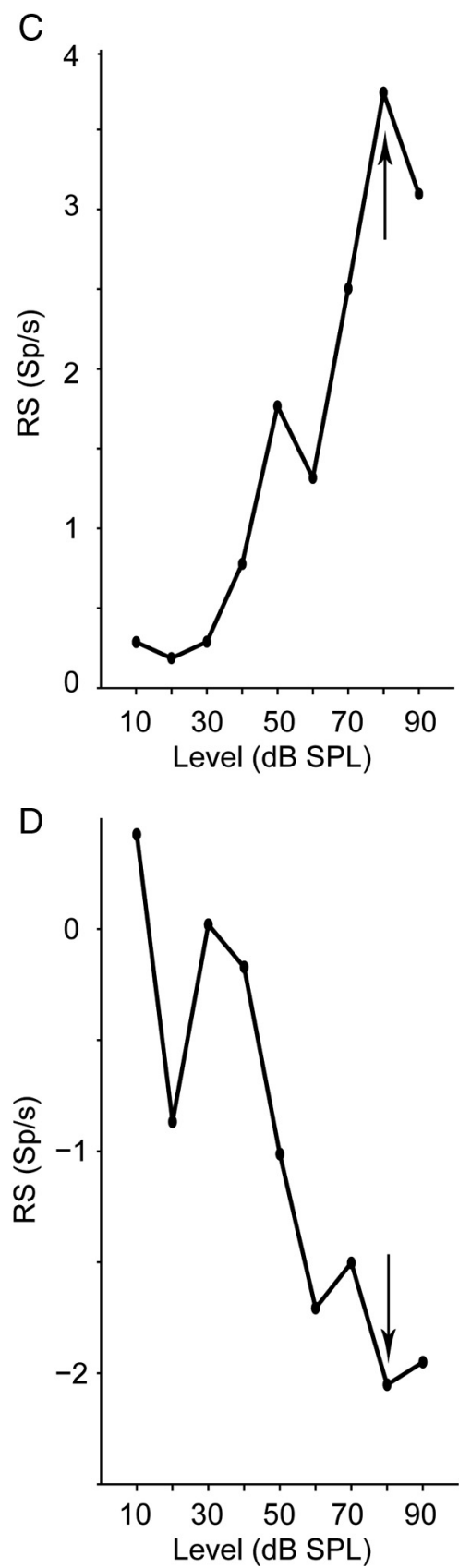

Figure 6. Neurons in field L can show suppressive song responses. $\boldsymbol{A}$, Representative rasters (left) and PSTH plots (right) from a single cell in a breeding female that gave an excitatory song response are arranged in rows by decreasing stimulus intensity. To improve readability, only responses from 40 to $90 \mathrm{~dB}$ SPL are shown. The same plot conventions as in Figure 2 are used. The amplitude envelope of the song stimulus (Fig. $1 A$, song no. 1) can be seen at the top of the raster and PSTH plots. The maximum response of this neuron is indicated in $\boldsymbol{C}$ by an arrow. $\boldsymbol{B}$, Representative rasters from a single cell in a nonbreeding female that gave a suppressive song response. The song stimulus was song no. 1 in Figure $1 A$. The maximum response of this neuron is indicated in $\boldsymbol{D}$ by an arrow. Plot conventions are as in $\boldsymbol{A}$. C, RS is plotted against song level for the neuron shown in $\boldsymbol{A}$. As song intensity increased, RS increased above zero, indicative of a excitatory response. $\boldsymbol{D}, \mathrm{RS}$ is plotted against song level for the neuron shown in $\boldsymbol{B}$. As song intensity increased, RS decreased below zero, indicative of a suppressive response. 
Table 5. Effects of breeding condition on all song responses pooled together

\begin{tabular}{|c|c|c|c|c|}
\hline & Breeding & Nonbreeding & Effect of breeding conditior & \\
\hline Number of excitatory (E) and suppressive $(S)$ song responses & $E=17, S=4$ & $E=23, S=14$ & $\chi_{(1, N=58)}^{2}=2.210$ & $p=0.137$ \\
\hline Maximum song $|\mathrm{RS}|(\mathrm{sp} / \mathrm{s})$ & $5.15 \pm 5.12$ & $3.86 \pm 4.15$ & $F_{(1,56)}=1.090$ & $p=0.301$ \\
\hline Song threshold (dB SPL) & $56.7 \pm 22.0$ & $57.3 \pm 20.2$ & $F_{(1,56)}=0.012$ & $p=0.912$ \\
\hline Song dynamic range ( $\mathrm{dB} S \mathrm{SP}$ ) & $28.6 \pm 23.1$ & $21.6 \pm 16.6$ & $F_{(1,56)}^{(1,0)}=1.762$ & $p=0.190$ \\
\hline
\end{tabular}

Values are means $\pm S D$ s, unless otherwise noted. The effect of breeding condition on the number of excitatory and suppressive song responses was assessed with Pearson's $\chi^{2}$ test. The effect of breeding condition on maximum song $|R S|$ was assessed with a one-way ANOVA. Song threshold and dynamic range were analyzed together in a one-way MANOVA.

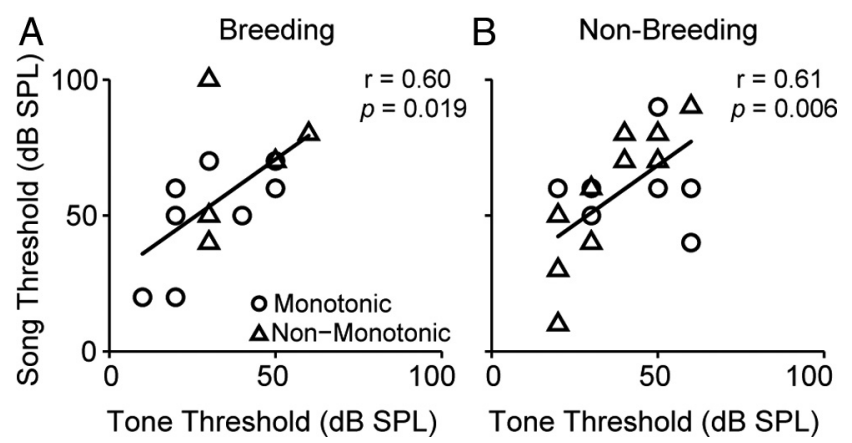

Figure 7. Song and tone thresholds are correlated within individual cells in both breeding and nonbreeding condition. $A$, Song and CF thresholds from individual breeding cells are plotted against one another. The circles represent units with monotonic tone responses; the triangles represent units with non-monotonic tone responses. Although song thresholds tend to be higher than those evoked by $C F$, thresholds are linearly correlated. $\boldsymbol{B}$, Nonbreeding condition song and tone thresholds are also linearly correlated. Plot conventions are as in $\boldsymbol{A}$. The number of cells and the number of birds (in parentheses) are as follows: breeding monotonic, $9(6)$; breeding non-monotonic, 6 (3); nonbreeding monotonic, 7 (5); nonbreeding non-monotonic, $12(7)$.

SPL; we observed similar results at all other sound levels tested (data not shown).

Thus, spontaneous firing rates, maximum firing rates, and sound-evoked response strengths of monotonic, but not nonmonotonic neurons, are all modulated by plasma $E_{2}$ in a dosedependent manner.

\section{Discussion}

\section{Hormonal regulation of auditory processing in the CNS}

The influence of sex steroid hormones on central auditory processing has received considerable attention, particularly for its clinical relevance. The latency of auditory brainstem responses (ABRs) change across the menstrual cycle and after hormone replacement therapy in adult women (Al-Mana et al., 2008, 2010). In addition, sound localization is impaired in women with Turner's syndrome, a chromosomal abnormality that results in estrogen deficiency (Hederstierna et al., 2009). Recent work in both humans and rodents has demonstrated that ERs are expressed widely in the mammalian auditory system, including auditory cortex (Stenberg et al., 2001; Charitidi et al., 2010; Tremere et al., 2011). Whether plasma hormones affect the response properties of single neurons in the mammalian auditory cortex, however, is currently unknown. One group has reported that mouse cortical multiunit responses to pup isolation calls differ between mothers and virgins, but the relative contributions of hormonal state and pup care experience cannot be separated in these experiments, and these two variables may interact (Miranda and Liu, 2009). In the current study, we demonstrate that single-unit auditory function in the telencephalon of an avian species is modulated by circulating reproductive hormones in a dose-dependent manner. Together, these findings highlight the need for detailed neurophysiological

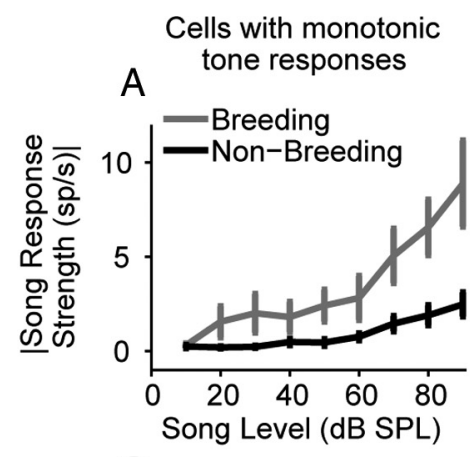

Cells with non-monotonic
tone responses

B
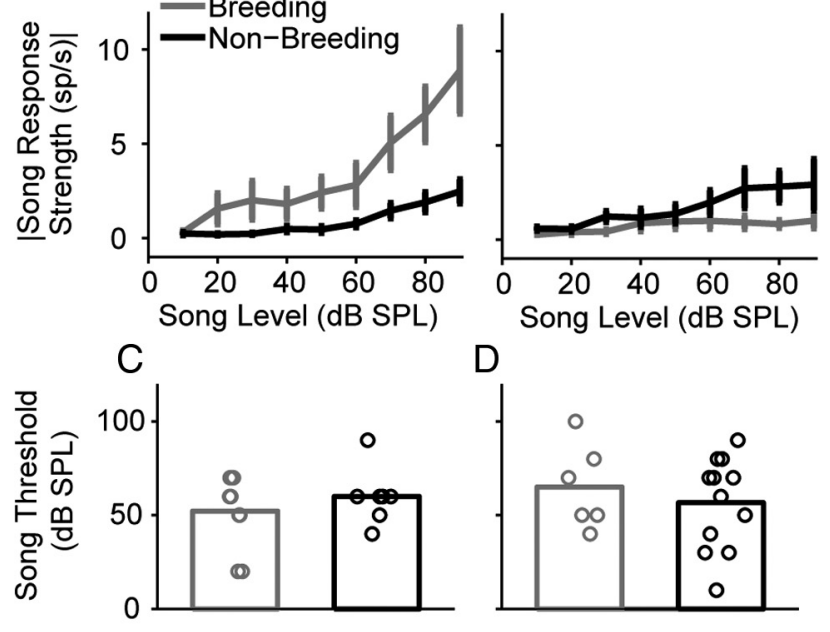

D
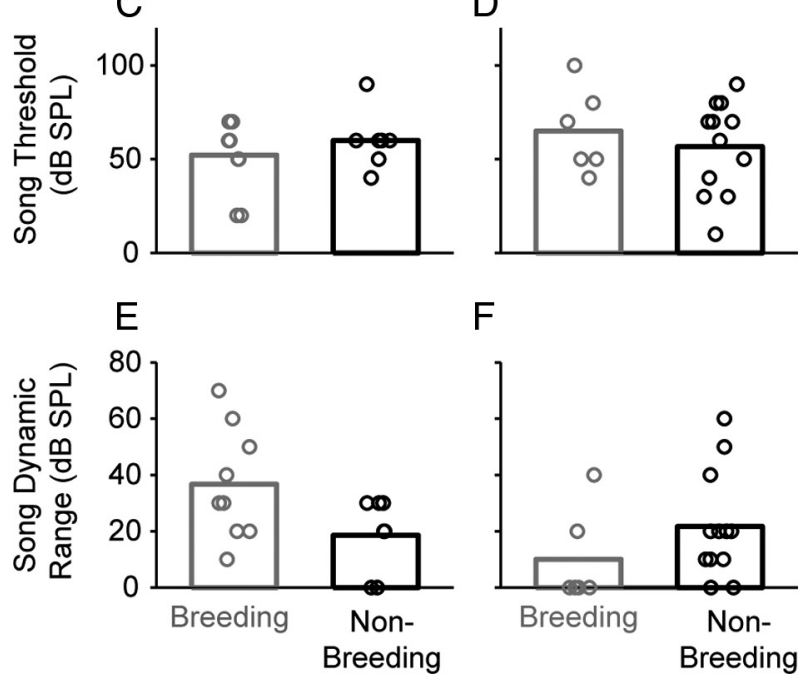

F

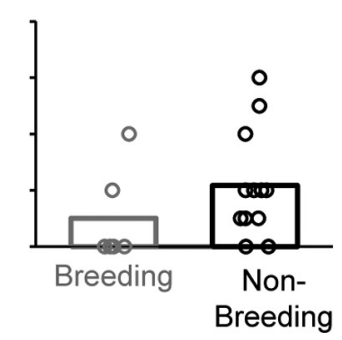

Figure 8. Breeding condition increases song response strengths and dynamic ranges in cells that have monotonic tone responses. $A$, Song $|R S|$ values in cells that have monotonic tone responses are plotted as a function of song level. Breeding condition (gray) increases song $|\mathrm{RS}|$ values compared with nonbreeding condition (black). B, Breeding condition does not significantly affect song $|R S|$ values in cells that have non-monotonic tone responses. $C, D$, Breeding condition does not affect song thresholds in cells that have either monotonic $(C)$ or nonmonotonic $(\boldsymbol{D})$ tone rate level functions. $\boldsymbol{E}$, Breeding condition marginally increases song dynamic ranges in neurons with monotonic tone responses. $\boldsymbol{F}$, Breeding condition does not significantly affect song dynamic ranges in neurons that have non-monotonic tone responses. Data in $\boldsymbol{A}$ and $\boldsymbol{B}$ are means \pm SEMs. The bars in $\boldsymbol{C}-\boldsymbol{F}$ are means; the circles represent individual neurons. The number of cells and the number of birds (in parentheses) are as follows: monotonic neurons: breeding, 9 (6), except at 10,20 , and $90 \mathrm{dBSPL}$ in $A$, where the sample sizes are $6(4), 7(5)$, and 8 (5), respectively; nonbreeding, 7 (5), except at $10 \mathrm{~dB}$ SPL in $A$, where the sample size was 5 (4); non-monotonic neurons: breeding, 6 (4), except at 10 and $20 \mathrm{dBSPL}$ in $\boldsymbol{B}$, where the sample sizes are 1 (1) and 4 (3), respectively; nonbreeding, 12 (7), except at 10, 80, and $90 \mathrm{~dB} \mathrm{SPL}$, where the sample sizes are $11(6), 10(6)$, and $9(6)$, respectively.

investigations of the mammalian auditory cortex under carefully controlled hormonal conditions.

The majority of work investigating hormonal modulation of central auditory function focuses on the rapid action of brainderived $\mathrm{E}_{2}$ to increase neuronal responsiveness in the songbird nucleus NCM (Pinaud and Tremere, 2012). NCM is a secondary nucleus downstream of field $\mathrm{L}$ and is specialized for conspecific 
song processing (Mello et al., 2004). In zebra finches, direct infusion of $\mathrm{E}_{2}$ into NCM increases single-unit evoked firing rates both locally in NCM and downstream in HVC (Tremere et al., 2009; Remage-Healey et al., 2010; Tremere and Pinaud, 2011; Remage-Healey and Joshi, 2012). Here, we report that $\mathrm{E}_{2}$ increases neuronal responsiveness in the primary auditory forebrain, indicating that the central effects of sex steroids are not limited to higher processing regions, but extend more generally within the auditory pathway. Surprisingly, the influence of sex steroids on auditory thresholds has never been assessed at a single-unit or multiunit level in the telencephalon. We show that monotonic field L cells have lower puretone thresholds and expanded song dynamic ranges under breeding condition. These results indicate that hormones do not simply modulate specialized forebrain processing tasks, such as neural song selectivity or discrimination. Instead, $E_{2}$ also modulates fundamental aspects of auditory forebrain function across a wide range of stimulus intensities.

\section{Cellular basis of $E_{2}$ modulation of field L neurons}

In NCM, blockade of ERs decreases neuronal activity (Tremere et al., 2009; Tremere and Pinaud, 2011), suggesting that $\mathrm{E}_{2}$ influences neuronal responses by binding directly to ERs. Field L does not express classical ERs (Jeong et al., 2011; Maney and Pinaud, 2011), and expresses little to no GPR30 (a nonclassical ER) in adulthood (Acharya and Veney, 2012), but demonstrates a clear sensitivity to $E_{2}$. Here, we discuss multiple possibilities for the cellular basis underlying estrogenic modulation of field $\mathrm{L}$ neurons.

One possibility is that $\mathrm{E}_{2}$ directly modulates activity in an area upstream of field L that contains ERs. In songbirds, ERs are absent in the auditory thalamus and midbrain (Gahr et al., 1993; Gahr, 2001). While no systematic study has examined ER expression in the songbird auditory brainstem, $\mathrm{ER} \alpha$ is expressed in three chicken brainstem nuclei: magnocellularis, angularis, and laminaris (Y. Wang and E. W. Rubel, unpublished observations). Additionally, $\mathrm{ER} \alpha$ is expressed in hair cells and support cells of the zebra finch inner ear (Noirot et al., 2009), and in the cochlear ganglion of Gambel's white-crowned sparrows (Y. Wang, E. A. Brenowitz, and E. W. Rubel, unpublished observations). All of these auditory regions are possible candidates for direct estrogenic influence.

Similarly, field L activity may be modulated by descending input from efferent regions that express ERs. Field L's only known source of top-down input is from the caudolateral mesopallium (Vates et al., 1996; Reiner et al., 2004) (Fig. 1B), a secondary auditory region that lacks ER expression (Gahr, 1990, 2001; Gahr et al., 1993; Metzdorf et al., 1999). $\mathrm{E}_{2}$ modulation
Monotonic
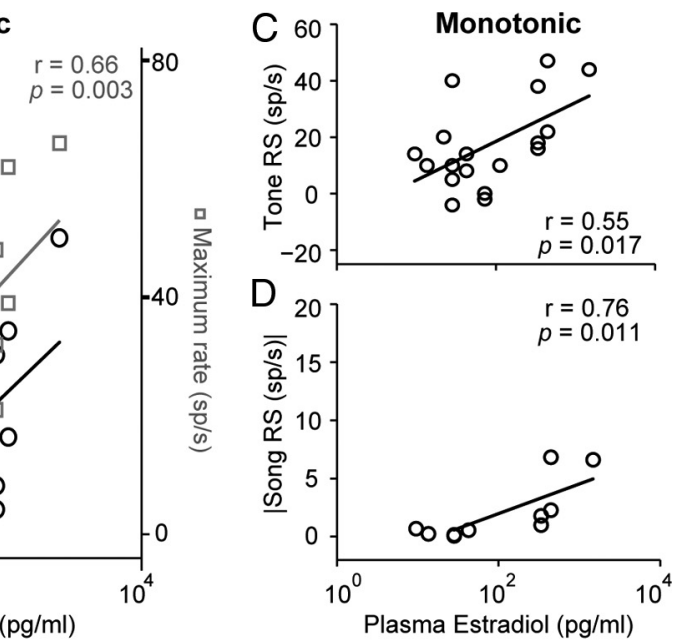

Non-Monotonic
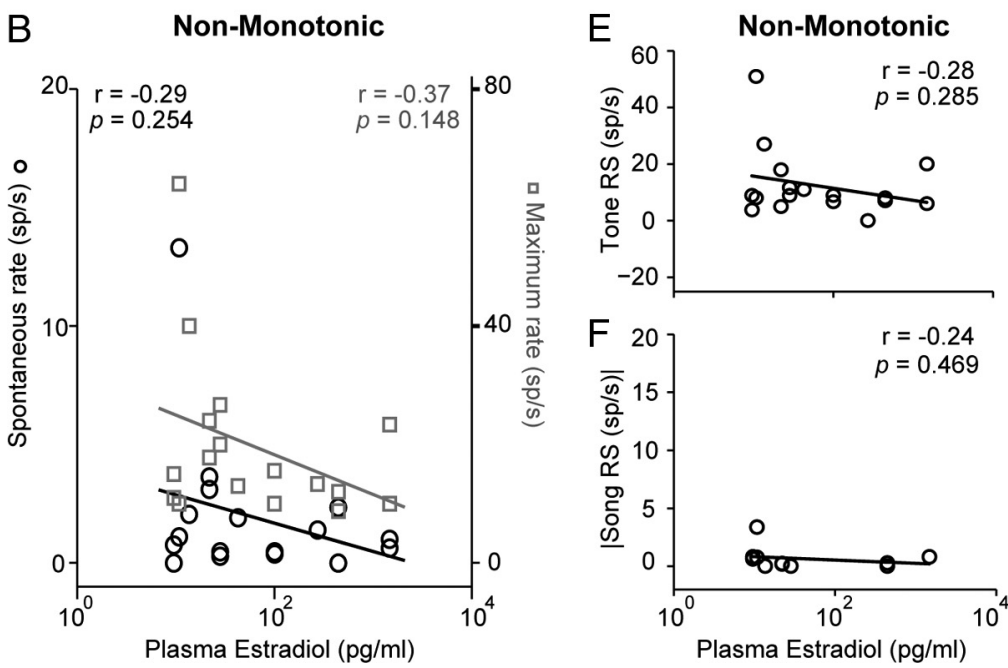

Figure 9. Plasma $E_{2}$ concentration predicts monotonic neuron firing rates and response strengths. $\boldsymbol{A}$, Spontaneous (black circles; left axis) and maximum evoked firing rates (gray squares; right axis) for individual monotonic neurons are plotted as a of circulating $E_{2}$ concentration. As plasma $E_{2}$ levels increase, spontaneous and maximum rates increase. Note that $E_{2}$ levels spontaneous or maximum evoked firing rates in non-monotonic neurons. The plot conventions are the same as in $A$. C, D

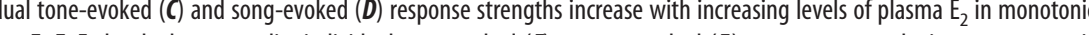

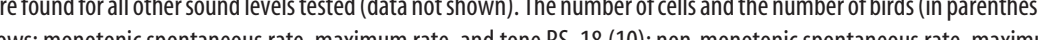
rate, and tone RS, 17 (10); monotonic song RS, 10 (7); non-monotonic song RS, 11 (8).

could be initiated instead in brain regions that are indirectly connected with field L. NCM, which expresses ERs (Bernard et al., 1999; Gahr, 2001; Saldanha and Coomaralingam, 2005; Jeong et al., 2011; Maney and Pinaud, 2011), is reciprocally connected to field $\mathrm{L}$ via three synapses, which pass through the medial and lateral portions of the caudal mesopallium (Fig. $1 B$ ). Additionally, the cup of the robust nucleus of the arcopallium is auditory responsive (Mello and Clayton, 1994) and may express ERs (Gahr et al., 1993). The cup sends projections to the shell of nucleus ovoidalis (Mello et al., 1998), which provides input into field L (Bonke et al., 1979; Vates et al., 1996). None of these pathways can be ruled out at this time.

Another possibility is that $\mathrm{E}_{2}$ modulates field $\mathrm{L}$ activity via monaminergic signaling. The songbird auditory system receives catecholaminergic innervation and these inputs are sensitive to hormonal state (Maney and Pinaud, 2011). For example, sex ste- 
roids regulate catecholamine turnover in field L (Barclay and Harding, 1988, 1990). In female white-throated sparrows (a congener to the white-crowned sparrow), systemic $\mathrm{E}_{2}$ increases the number of catecholaminergic cells in locus ceruleus (LeBlanc et al., 2007) and increases the density of monoaminergic fibers in the auditory midbrain and forebrain (Matragrano et al., 2011, 2012). Furthermore, monoamines modulate songbird auditory forebrain physiology (Dave et al., 1998; Shea and Margoliash, 2003; Cardin and Schmidt, 2004) and behavioral responses to song playback (Appeltants et al., 2002; Riters and Pawlisch, 2007; Vyas et al., 2009; Pawlisch et al., 2011). Future experiments should test whether intact monoamine signaling is necessary to mediate the effects of systemic $\mathrm{E}_{2}$ on field L neurons.

\section{Dose-responsive effects of $E_{2}$ on central sensory physiology}

Few studies have addressed whether the effects of circulating $\mathrm{E}_{2}$ on central sensory physiology scale with hormone concentration in a graded manner or are exerted in an all-or-none fashion once hormone levels reach some critical level (Oshima and Gorbman, 1969). Here, we demonstrate that in monotonic neurons, firing rates and response strengths gradually increase with increasing plasma $\mathrm{E}_{2}$. These findings suggest that individual auditory responsiveness is maximal when plasma $\mathrm{E}_{2}$ is highest (during courtship and copulation) (Wingfield and Farner, 1978) and is less sensitive at other times during the breeding season, when intersex communication may be less important. Given the metabolic cost of increased neural activity (Niven and Laughlin, 2008), a graded hormonal effect may serve to reduce unnecessary energy expenditure postmating, when other behaviors associated with the breeding season (e.g., feeding young, molting) occur.

\section{Cell-specific effect of $E_{2}$}

We found that $\mathrm{E}_{2}$ has robust effects on monotonic auditory function while leaving non-monotonic cell processing unchanged. While the precise roles of monotonic and non-monotonic cells in auditory coding are still a matter of speculation, several hypotheses have been proposed. One of these hypotheses, the level tolerance model, suggests that non-monotonic neurons maintain sound source identity over a wide range of intensities, allowing the frequency content of a complex stimulus to be encoded by neuronal firing rates without the confounding influence of stimulus level (Sadagopan and Wang, 2008). If this model is true, then our findings suggest that $E_{2}$ may enhance sound responses in monotonic neurons to allow better signal detection in the breeding season, while the stability of non-monotonic cells might ensure that signal identity remains constant under variable listening conditions. Maintaining a consistent representation of sounds across seasons could be important for the accurate recognition of species or individuals within a flock.

\section{Disparate effects of $E_{2}$ within auditory pathway}

In a previous study, systemic $\mathrm{E}_{2}$ treatment elevated $\mathrm{ABR}$ thresholds in female white-crowned sparrows (Caras et al., 2010). This result seems to contradict the findings presented here. To reconcile this apparent discrepancy, it is important to note a few important differences between the studies. First, the ABR is a population response, generated by electrical activity in the auditory nerve and brainstem (Hall, 2007). Because no particular pure-tone frequency will elicit an optimal response in all neurons contributing to the ABR, the threshold is actually a measurement of sensitivity to a suboptimal stimulus. Conversely, in the current study, we calculated threshold at the optimal stimulus of an individual neuron: its CF. Furthermore, because the ABR is a pooled response recorded far-field (Jewett et al., 1970; Jewett and Williston, 1971), it is better described as a measure of neural synchrony, as opposed to firing rate. It is therefore difficult to compare the two measurements directly. Regardless of the methodological differences between the two studies, the possibility still remains that sex steroids have heterogeneous effects on separate portions of the ascending auditory system. This divergence could be explained by differences in hormone receptor expression patterns or mechanisms of hormonal action, as discussed above.

\section{References}

Acharya KD, Veney SL (2012) Characterization of the G-protein coupled membrane bound estrogen receptor GPR30 in the zebra finch brain reveals a sex difference in gene and protein expression. Dev Neurobiol 72:1433-1446. CrossRef Medline

Al-Mana D, Ceranic B, Djahanbakhch O, Luxon LM (2008) Hormones and the auditory system: a review of physiology and pathophysiology. Neuroscience 153:881-900. CrossRef Medline

Al-Mana D, Ceranic B, Djahanbakhch O, Luxon LM (2010) Alteration in auditory function during the ovarian cycle. Hear Res 268:114-122. CrossRef Medline

Appeltants D, Del Negro C, Balthazart J (2002) Noradrenergic control of auditory information processing in female canaries. Behav Brain Res 133: 221-235. CrossRef Medline

Avey MT, Phillmore LS, MacDougall-Shackleton SA (2005) Immediate early gene expression following exposure to acoustic and visual components of courtship in zebra finches. Behav Brain Res 165:247-253. CrossRef Medline

Barclay SR, Harding CF (1988) Androstenedione modulation of monoamine levels and turnover in hypothalamic and vocal control nuclei in the male zebra finch: steroid effects on brain monoamines. Brain Res 459: 333-343. CrossRef Medline

Barclay SR, Harding CF (1990) Differential modulation of monoamine levels and turnover rates by estrogen and/or androgen in hypothalamic and vocal control nuclei of male zebra finches. Brain Res 523:251-262. CrossRef Medline

Bass AH (2008) Steroid-dependent plasticity of vocal motor systems: novel insights from teleost fish. Brain Res Rev 57:299-308. CrossRef Medline

Bernard DJ, Bentley GE, Balthazart J, Turek FW, Ball GF (1999) Androgen receptor, estrogen receptor alpha, and estrogen receptor beta show distinct patterns of expression in forebrain song control nuclei of European starlings. Endocrinology 140:4633-4643. CrossRef Medline

Bonke D, Scheich H, Langner G (1979) Responsiveness of units in the auditory neostriatum of the Guinea Fowl (Numida meleagris) to speciesspecific calls and synthetic stimuli. J Comp Physiol 132:243-255. CrossRef

Brackenbury JH (1979) Power capabilities of the avian sound-producing system. J Exp Biol 78:163-166.

Brenowitz EA (1982) The active space of red-winged blackbird song. J Comp Physiol A Neuroethol Sens Neural Behav Physiol 147:511-522.

Brenowitz EA (2008) Plasticity of the song control system in adult birds. In: Neuroscience of birdsong (Zeigler P, Marler P, eds), p 332. New York: Cambridge UP.

Brenowitz EA, Nalls B, Wingfield JC, Kroodsma DE (1991) Seasonal changes in avian song nuclei without seasonal changes in song repertoire. J Neurosci 11:1367-1374. Medline

Caras ML, Brenowitz E, Rubel EW (2010) Peripheral auditory processing changes seasonally in Gambel's white-crowned sparrow. J Comp Physiol A Neuroethol Sens Neural Behav Physiol 196:581-599. CrossRef Medline

Cardin JA, Schmidt MF (2004) Noradrenergic inputs mediate state dependence of auditory responses in the avian song system. J Neurosci 24:77457753. CrossRef Medline

Catchpole CK, Slater PJB (1995) Bird song: biological themes and variations. Cambridge, UK: Cambridge UP.

Charitidi K, Frisina RD, Vasilyeva ON, Zhu X, Canlon B (2010) Expression patterns of estrogen receptors in the central auditory system change in prepubertal and aged mice. Neuroscience 170:1270-1281. CrossRef Medline

Cynx J, Williams H, Nottebohm F (1992) Hemispheric differences in avian song discrimination. Proc Natl Acad Sci U S A 89:1372-1375. CrossRef Medline

Dave AS, Yu AC, Margoliash D (1998) Behavioral state modulation of au- 
ditory activity in a vocal motor system. Science 282:2250-2254. CrossRef Medline

de la Rocha J, Marchetti C, Schiff M, Reyes AD (2008) Linking the response properties of cells in auditory cortex with network architecture: cotuning versus lateral inhibition. J Neurosci 28:9151-9163. CrossRef Medline

Dixon WJ (1950) Analysis of extreme values. Ann Math Stat 21:488-506. CrossRef

Fortune ES, Margoliash D (1992) Cytoarchitectonic organization and morphology of cells of the field L complex in male zebra finches (Taenopygia guttata). J Comp Neurol 325:388-404. CrossRef Medline

Gahr M (1990) Localization of androgen receptors and estrogen receptors in the same cells of the songbird brain. Proc Natl Acad Sci U S A 87:94459448. CrossRef Medline

Gahr M (2001) Distribution of sex steroid hormone receptors in the avian brain: functional implications for neural sex differences and sexual behaviors. Microsc Res Tech 55:1-11. CrossRef Medline

Gahr M, Güttinger HR, Kroodsma DE (1993) Estrogen receptors in the avian brain: survey reveals general distribution and forebrain areas unique to songbirds. J Comp Neurol 327:112-122. CrossRef Medline

George I, Vernier B, Richard JP, Hausberger M, Cousillas H (2004) Hemispheric specialization in the primary auditory area of awake and anesthetized starlings (Sturnus vulgaris). Behav Neurosci 118:597-610. CrossRef Medline

George I, Cousillas H, Richard JP, Hausberger M (2005) State-dependent hemispheric specialization in the songbird brain. J Comp Neurol 488:4860. CrossRef Medline

Hall JW (2007) New handbook of auditory evoked responses. Boston: Allyn and Bacon.

Hauber ME, Cassey P, Woolley SM, Theunissen FE (2007) Neurophysiological response selectivity for conspecific songs over synthetic sounds in the auditory forebrain of non-singing female songbirds. J Comp Physiol A Neuroethol Sens Neural Behav Physiol 193:765-774. Medline

Hederstierna C, Hultcrantz M, Rosenhall U (2009) Estrogen and hearing from a clinical point of view; characteristics of auditory function in women with Turner syndrome. Hear Res 252:3-8. CrossRef Medline

Henry KS, Lucas JR (2009) Vocally correlated seasonal auditory variation in the house sparrow (Passer domesticus). J Exp Biol 212:3817-3822. CrossRef Medline

Jeong JK, Burrows K, Tremere LA, Pinaud R (2011) Neurochemical organization and experience-dependent activation of estrogen-associated circuits in the songbird auditory forebrain. Eur J Neurosci 34:283-291. CrossRef Medline

Jewett DL, Williston JS (1971) Auditory-evoked far fields averaged from the scalp of humans. Brain 94:681-696. CrossRef Medline

Jewett DL, Romano MN, Williston JS (1970) Human auditory evoked potentials: possible brain stem components detected on the scalp. Science 167:1517-1518. CrossRef Medline

Kim G, Doupe A (2011) Organized representation of spectrotemporal features in songbird auditory forebrain. J Neurosci 31:16977-16990. CrossRef Medline

LeBlanc MM, Goode CT, MacDougall-Shackleton EA, Maney DL (2007) Estradiol modulates brainstem catecholaminergic cell groups and projections to the auditory forebrain in a female songbird. Brain Res 1171:93103. CrossRef Medline

Maney DL, Pinaud R (2011) Estradiol-dependent modulation of auditory processing and selectivity in songbirds. Front Neuroendocrinol 32:287302. CrossRef Medline

Maney DL, Cho E, Goode CT (2006) Estrogen-dependent selectivity of genomic responses to birdsong. Eur J Neurosci 23:1523-1529. CrossRef Medline

Matragrano LL, Sanford SE, Salvante KG, Sockman KW, Maney DL (2011) Estradiol-dependent catecholaminergic innervation of auditory areas in a seasonally breeding songbird. Eur J Neurosci 34:416-425. CrossRef Medline

Matragrano LL, Sanford SE, Salvante KG, Beaulieu M, Sockman KW, Maney DL (2012) Estradiol-dependent modulation of serotonergic markers in auditory areas of a seasonally breeding songbird. Behav Neurosci 126: 110-122. CrossRef Medline

Meitzen J, Perkel DJ, Brenowitz EA (2007a) Seasonal changes in intrinsic electrophysiological activity of song control neurons in wild song sparrows. J Comp Physiol A Neuroethol Sens Neural Behav Physiol 193:677683. CrossRef Medline
Meitzen J, Moore IT, Lent K, Brenowitz EA, Perkel DJ (2007b) Steroid hormones act transsynaptically within the forebrain to regulate neuronal phenotype and song stereotypy. J Neurosci 27:12045-12057. CrossRef Medline

Meitzen J, Thompson CK, Choi H, Perkel DJ, Brenowitz EA (2009a) Time course of changes in Gambel's white-crowned sparrow song behavior following transitions in breeding condition. Horm Behav 55:217-227. CrossRef Medline

Meitzen J, Weaver AL, Brenowitz EA, Perkel DJ (2009b) Plastic and stable electrophysiological properties of adult avian forebrain song-control neurons across changing breeding conditions. J Neurosci 29:6558-6567. CrossRef Medline

Mello CV, Clayton DF (1994) Song-induced ZENK gene expression in auditory pathways of songbird brain and its relation to the song control system. J Neurosci 14:6652-6666. Medline

Mello CV, Pinaud R, Ribeiro S (1998) Noradrenergic system of the zebra finch brain: immunocytochemical study of dopamine-beta-hydroxylase. J Comp Neurol 400:207-228. CrossRef Medline

Mello CV, Velho TA, Pinaud R (2004) Song-induced gene expression: a window on song auditory processing and perception. Ann N Y Acad Sci 1016:263-281. CrossRef Medline

Metzdorf R, Gahr M, Fusani L (1999) Distribution of aromatase, estrogen receptor, and androgen receptor mRNA in the forebrain of songbirds and nonsongbirds. J Comp Neurol 407:115-129. CrossRef Medline

Middleton J (1965) Testicular responses of house sparrows and whitecrowned sparrows to short daily photoperiods with low intensities of light. Physiol Zool 38:255-266.

Miranda JA, Liu RC (2009) Dissecting natural sensory plasticity: hormones and experience in a maternal context. Hear Res 252:21-28. CrossRef Medline

Müller CM, Leppelsack HJ (1985) Feature extraction and tonotopic organization in the avian auditory forebrain. Exp Brain Res 59:587-599. Medline

Nagel KI, Doupe AJ (2008) Organizing principles of spectro-temporal encoding in the avian primary auditory area field L. Neuron 58:938-955. CrossRef Medline

Nemeth E (2004) Measuring the sound pressure level of the song of the Screaming Piha Lipaugus vociferans: one of the loudest birds in the world. Bioacoustics 14:225-228. CrossRef

Niven JE, Laughlin SB (2008) Energy limitation as a selective pressure on the evolution of sensory systems. J Exp Biol 211:1792-1804. CrossRef Medline

Noirot IC, Adler HJ, Cornil CA, Harada N, Dooling RJ, Balthazart J, Ball GF (2009) Presence of aromatase and estrogen receptor alpha in the inner ear of zebra finches. Hear Res 252:49-55. CrossRef Medline

Nottebohm F (1981) A brain for all seasons: cyclical anatomical changes in song control nuclei of the canary brain. Science 214:1368-1370. CrossRef Medline

Oshima K, Gorbman A (1969) Effect of estradiol on NaCl-evoked olfactory bulbar potentials in goldfish: dose-response relationships. Gen Comp Endocrinol 13:92-97. CrossRef Medline

Park KH, Meitzen J, Moore IT, Brenowitz EA, Perkel DJ (2005) Seasonallike plasticity of spontaneous firing rate in a songbird pre-motor nucleus. J Neurobiol 64:181-191. CrossRef Medline

Pawlisch BA, Stevenson SA, Riters LV (2011) $\alpha_{1}$-Noradrenegic receptor antagonism disrupts female songbird responses to male song. Neurosci Lett 496:20-24. CrossRef Medline

Phan ML, Vicario DS (2010) Hemispheric differences in processing of vocalizations depend on early experience. Proc Natl Acad Sci U S A 107: 2301-2306. CrossRef Medline

Phillmore LS, Veysey AS, Roach SP (2011) Zenk expression in auditory regions changes with breeding condition in male Black-capped chickadees (Poecile atricapillus). Behav Brain Res 225:464-472. CrossRef Medline

Pinaud R, Tremere LA (2012) Control of central auditory processing by a brain-generated oestrogen. Nat Rev Neurosci 13:521-527. CrossRef Medline

Poirier C, Boumans T, Verhoye M, Balthazart J, Van der Linden A (2009) Own-song recognition in the songbird auditory pathway: selectivity and lateralization. J Neurosci 29:2252-2258. CrossRef Medline

Polley DB, Steinberg EE, Merzenich MM (2006) Perceptual learning directs auditory cortical map reorganization through top-down influences. J Neurosci 26:4970-4982. CrossRef Medline 
Recanzone GH, Guard DC, Phan ML (2000) Frequency and intensity response properties of single neurons in the auditory cortex of the behaving macaque monkey. J Neurophysiol 83:2315-2331. Medline

Reiner A, Perkel DJ, Mello CV, Jarvis ED (2004) Songbirds and the revised avian brain nomenclature. Ann N Y Acad Sci 1016:77-108. CrossRef Medline

Remage-Healey L, Joshi NR (2012) Changing neuroestrogens within the auditory forebrain rapidly transform stimulus selectivity in a downstream sensorimotor nucleus. J Neurosci 32:8231-8241. CrossRef Medline

Remage-Healey L, Coleman MJ, Oyama RK, Schlinger BA (2010) Brain estrogens rapidly strengthen auditory encoding and guide song preference in a songbird. Proc Natl Acad Sci U S A 107:3852-3857. CrossRef Medline

Remage-Healey L, Dong SM, Chao A, Schlinger BA (2012) Sex-specific, rapid neuroestrogen fluctuations and neurophysiological actions in the songbird auditory forebrain. J Neurophysiol 107:1621-1631. CrossRef Medline

Riters LV, Pawlisch BA (2007) Evidence that norepinephrine influences responses to male courtship song and activity within song control regions and the ventromedial nucleus of the hypothalamus in female European starlings. Brain Res 1149:127-140. CrossRef Medline

Rorabacher DB (1991) Statistical treatment for rejection of deviant values: critical values of Dixon's "Q" parameter and related subrange ratios at the 95\% confidence level. Anal Chem 63:139-146. CrossRef

Sadagopan S, Wang X (2008) Level invariant representation of sounds by populations of neurons in primary auditory cortex. J Neurosci 28:34153426. CrossRef Medline

Saldanha CJ, Coomaralingam L (2005) Overlap and co-expression of estrogen synthetic and responsive neurons in the songbird brain-a doublelabel immunocytochemical study. Gen Comp Endocrinol 141:66-75. CrossRef Medline

Sanford SE, Lange HS, Maney DL (2010) Topography of estradiolmodulated genomic responses in the songbird auditory forebrain. Dev Neurobiol 70:73-86. CrossRef Medline

Sen K, Theunissen FE, Doupe AJ (2001) Feature analysis of natural sounds in the songbird auditory forebrain. J Neurophysiol 86:1445-1458. Medline

Shea SD, Margoliash D (2003) Basal forebrain cholinergic modulation of auditory activity in the zebra finch song system. Neuron 40:1213-1226. CrossRef Medline

Smith GT, Brenowitz EA, Wingfield JC, Baptista LF (1995) Seasonal changes in song nuclei and song behavior in Gambel's white-crowned sparrows. J Neurobiol 28:114-125. CrossRef Medline

Smith GT, Brenowitz EA, Wingfield JC (1997) Roles of photoperiod and testosterone in seasonal plasticity of the avian song control system. J Neurobiol 32:426-442. CrossRef Medline

Soma KK, Tramontin AD, Featherstone J, Brenowitz EA (2004) Estrogen contributes to seasonal plasticity of the adult avian song control system. J Neurobiol 58:413-422. CrossRef Medline

Stenberg AE, Wang H, Fish J 3rd, Schrott-Fischer A, Sahlin L, Hultcrantz M (2001) Estrogen receptors in the normal adult and developing human inner ear and in Turner's syndrome. Hear Res 157:87-92. CrossRef Medline

Sutter ML, Schreiner CE (1995) Topography of intensity tuning in cat primary auditory cortex: single-neuron versus multiple-neuron recordings. J Neurophysiol 73:190-204. Medline

Theunissen FE, Amin N, Shaevitz SS, Woolley SM, Fremouw T, Hauber ME (2004) Song selectivity in the song system and in the auditory forebrain. Ann N Y Acad Sci 1016:222-245. CrossRef Medline

Tramontin AD, Hartman VN, Brenowitz EA (2000) Breeding conditions induce rapid and sequential growth in adult avian song control circuits: a model of seasonal plasticity in the brain. J Neurosci 20:854-861. Medline

Tramontin AD, Wingfield JC, Brenowitz EA (2003) Androgens and estrogens induce seasonal-like growth of song nuclei in the adult songbird brain. J Neurobiol 57:130-140. CrossRef Medline

Tremere LA, Pinaud R (2011) Brain-generated estradiol drives long-term optimization of auditory coding to enhance the discrimination of communication signals. J Neurosci 31:3271-3289. CrossRef Medline

Tremere LA, Jeong JK, Pinaud R (2009) Estradiol shapes auditory processing in the adult brain by regulating inhibitory transmission and plasticityassociated gene expression. J Neurosci 29:5949-5963. CrossRef Medline

Tremere LA, Burrows K, Jeong JK, Pinaud R (2011) Organization of estrogen-associated circuits in the mouse primary auditory cortex. J Exp Neurosci 2011:45-60. CrossRef Medline

Vates GE, Broome BM, Mello CV, Nottebohm F (1996) Auditory pathways of caudal telencephalon and their relation to the song system of adult male zebra finches. J Comp Neurol 366:613-642. CrossRef Medline

Vyas A, Harding C, Borg L, Bogdan D (2009) Acoustic characteristics, early experience, and endocrine status interact to modulate female zebra finches' behavioral responses to songs. Horm Behav 55:50-59. CrossRef Medline

Watkins PV, Barbour DL (2011) Rate-level responses in awake marmoset auditory cortex. Hear Res 275:30-42. CrossRef Medline

Wild JM, Karten HJ, Frost BJ (1993) Connections of the auditory forebrain in the pigeon (Columba livia). J Comp Neurol 337:32-62. CrossRef Medline

Wingfield JC, Farner DS (1978) The annual cycle of plasma irLH and steroid hormones in feral populations of the white-crowned sparrow, Zonotrichia leucophrys gambelii. Biol Reprod 19:1046-1056. CrossRef Medline

Wingfield JC, Crim JW, Mattocks PW Jr, Farner DS (1979) Responses of photosensitive and photorefractory male white-crowned sparrows (Zonotrichia leucophrys gambelii) to synthetic mammalian luteinizing hormone releasing hormone (syn-LHRH). Biol Reprod 21:801-806. CrossRef Medline 